Report prepared for Wrangell-St. Elias National Park and Preserve

\title{
Mercury in Fishes from Wrangell-St. Elias National Park and Preserve, Alaska
}

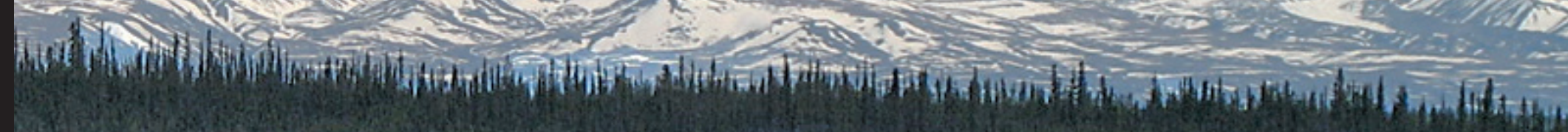

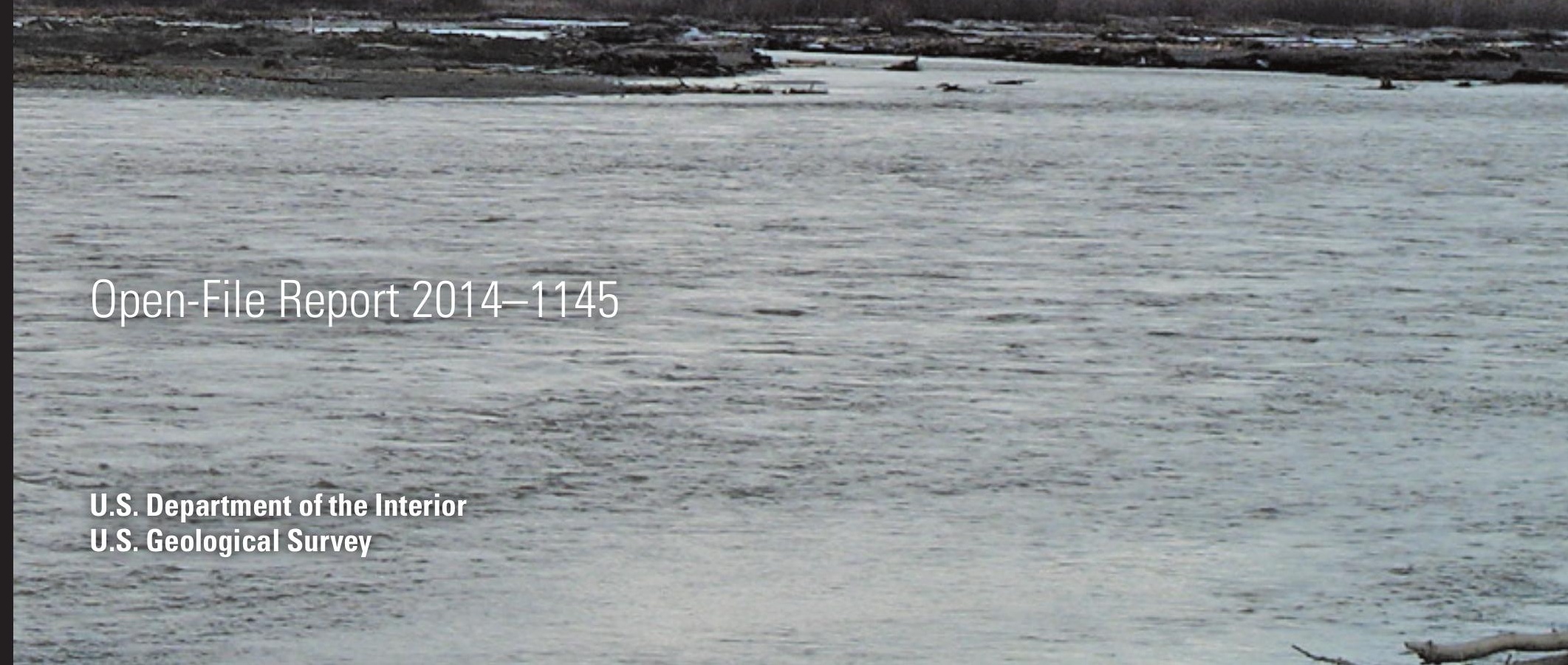


Cover: Photograph of Mount Drum, Wrangell-St. Elias National Park and Preserve, 2007.

Photograph taken from the Tok Cutoff by J. Willacker, U.S. Geological Survey. 


\section{Mercury in Fishes from Wrangell-St. Elias National Park and Preserve, Alaska}

By Brandon M. Kowalski, James J. Willacker, Jr., Christian E. Zimmerman, and Collin A. Eagles-Smith

Report prepared for Wrangell-St. Elias National Park and Preserve

Open-File Report 2014-1145

U.S. Department of the Interior

U.S. Geological Survey 


\section{U.S. Department of the Interior \\ SALLY JEWELL, Secretary}

\section{U.S. Geological Survey \\ Suzette M. Kimball, Acting Director}

U.S. Geological Survey, Reston, Virginia: 2014

For more information on the USGS-the Federal source for science about the Earth,

its natural and living resources, natural hazards, and the environment-visit

http://www.usgs.gov or call 1-888-ASK-USGS

For an overview of USGS information products, including maps, imagery, and publications, visit $h$ ttp://www.usgs.gov/pubprod

To order this and other USGS information products, visit http://store.usgs.gov

Suggested citation:

Kowalski, B.K., Willacker, J.J., Zimmerman, C.E., and Eagles-Smith, C.A., 2014, Mercury in fishes from Wrangell-St. Elias National Park and Preserve, Alaska: U.S. Geological Survey Open-File Report 2014-1145, 26 p., http://dx.doi.org/10.3133/ofr20141145.

ISSN 2331-1258 (online)

Any use of trade, firm, or product names is for descriptive purposes only and does not imply endorsement by the U.S. Government.

Although this information product, for the most part, is in the public domain, it also may contain copyrighted materials as noted in the text. Permission to reproduce copyrighted items must be secured from the copyright owner. 


\section{Contents}

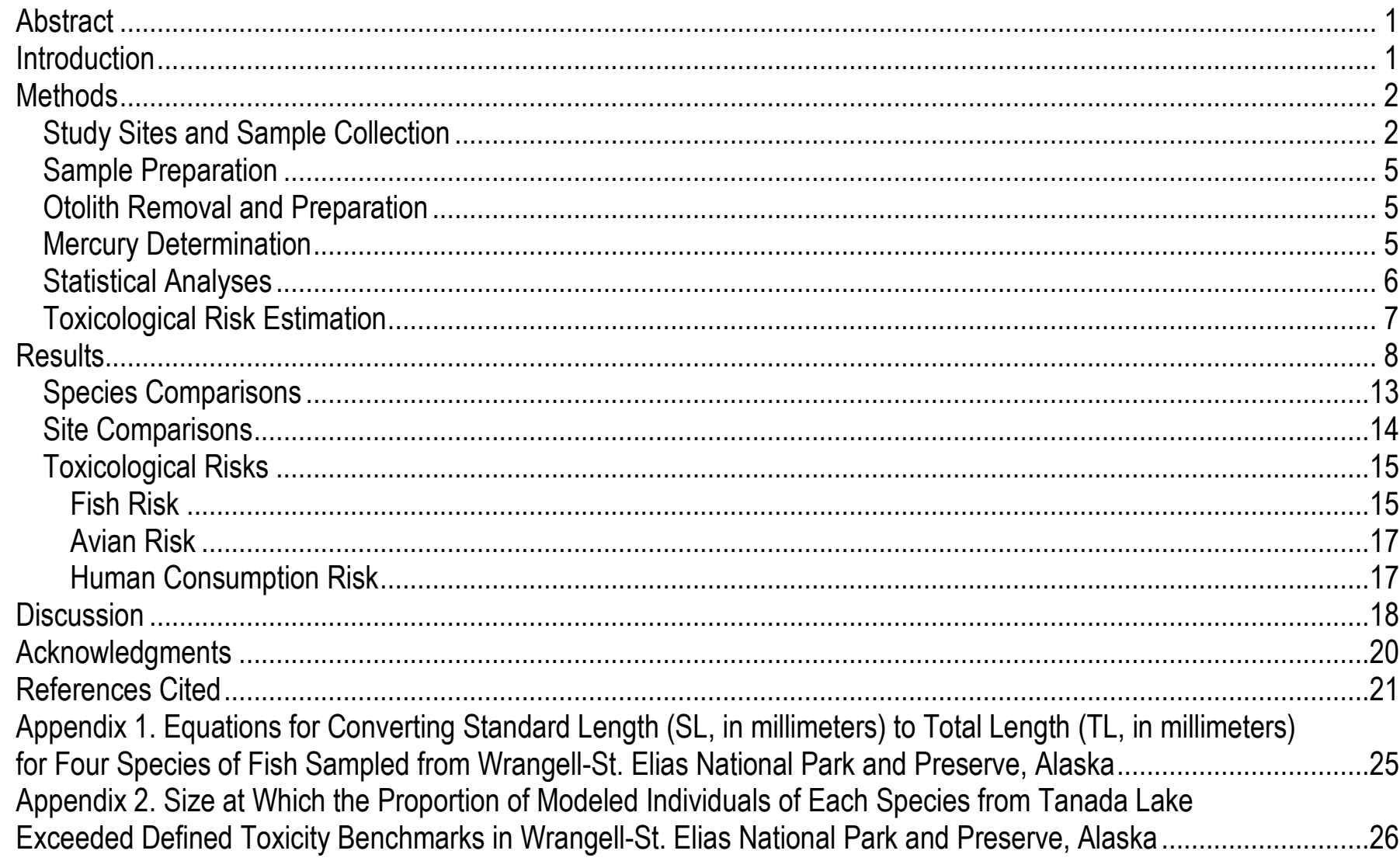




\section{Figures}

Figure 1. Schematic of four study lakes in Wrangell-St. Elias National Park and Preserve, Alaska.

Figure 2. Arithmetic-mean total mercury concentrations ( $\mathrm{THg}$, in nanograms per gram wet weight [ng/g ww]) \pm 1 standard error in fish species collected from four lakes in Wrangell-St. Elias National Park and Preserve, Alaska....... 9 Figure 3. Linear relationships between standard length (in millimeters, $[\mathrm{mm}]$ ) and total mercury concentrations (THg, in nanograms per gram dry weight [ng/g dw]) in fish muscle of (A) Arctic grayling, (B) burbot, (C) lake trout, and (D) rainbow trout sampled from Wrangell-St. Elias National Park and Preserve, Alaska

Figure 4. Linear relationships between fish age (in years) and total mercury concentrations ( $\mathrm{THg}$, in nanograms per gram dry weight [ng/g dw]) in fish muscle of (A) Arctic grayling, (B) burbot, (C) lake trout, and (D) rainbow trout sampled from Wrangell-St. Elias National Park and Preserve, Alaska.

Figure 5. Logarithmic relationships between fish age (in years) and standard length (in millimeters [mm]) of (A) Arctic grayling, (B) burbot, (C) lake trout, and (D) rainbow trout sampled from Wrangle-St. Elias National Park and Preserve, Alaska.

Figure 6. Back-transformed least-square mean total mercury concentrations (THg, in nanograms per gram wet weight [ng/g ww]) in muscle of fishes from Tanada Lake, Wrangell-St. Elias National Park and Preserve, Alaska ..... 13 Figure 7. Back-transformed least-square mean total mercury concentrations ( $\mathrm{THg}$, in nanograms per gram wet weight [ng/g ww]) in muscle of $(A)$ lake trout, and $(B)$ burbot from lakes in Wrangell-St. Elias National Park and Preserve, Alaska

Figure 8. Modeled relationship between fish size and the percentage of Arctic grayling, burbot, and lake trout from Tanada Lake, Wrangell-St. Elias National Park and Preserve, Alaska, that exceed defined toxicological benchmarks for fishes, avian, and human consumers.

\section{Tables}

Table 1.SSite locations and sample information for sites sampled in Wrangell-St. Elias National Park and Preserve, Alaska 4

Table 2. Comparison of coefficient of determination $\left(R^{2}\right)$ and $P$-values between mercury-age and mercury-length regressions from fish sampled in Wrangell-St. Elias National Park and Preserve, Alaska 9

Table 3. Percentage of fish from four lakes in Wrangell-St. Elias National Park and Preserve, Alaska, with raw (that is, non-size corrected) total mercury concentrations exceeding defined toxicity benchmarks for fish, avian, and human risk 


\section{Conversion Factors and Datum}

SI to Inch/Pound

\begin{tabular}{lll}
\hline & \multicolumn{1}{c}{ Multiply } & \multicolumn{1}{c}{ To obtain } \\
\hline millimeter $(\mathrm{mm})$ & Length & \\
meter $(\mathrm{m})$ & 0.03937 & inch (in.) \\
kilometer $(\mathrm{km})$ & 3.281 & foot (ft) \\
\hline & 0.6214 & mile (mi) \\
\hline acre & Area & \\
\hline & 0.0015625 & square mile $\left(\mathrm{mi}^{2}\right)$ \\
\hline gram $(\mathrm{g})$ & Mass & \\
\hline
\end{tabular}

Temperature in degrees Celsius $\left({ }^{\circ} \mathrm{C}\right)$ may be converted to degrees Fahrenheit $\left({ }^{\circ} \mathrm{F}\right)$ as follows:

${ }^{\circ} \mathrm{F}=\left(1.8 x^{\circ} \mathrm{C}\right)+32$.

\section{Datum}

Vertical coordinate information is referenced to the North American Vertical Datum of 1988 (NAVD 88).

Elevation, as used in this report, refers to distance above the vertical datum. 


\section{Abbreviations and Acronyms}

\begin{tabular}{ll}
\hline AIC & Akaike's Information Criterion \\
AK-DHSS & Alaska Department of Health and Social Services \\
ANCOVA & Analysis of Covariance \\
dw & dry weight \\
EPA & U.S. Environmental Protection Agency \\
Hg & mercury \\
LOER & lowest-observed-effects-residue \\
MeHg & methylmercury \\
$\mathbf{n}$ & sample size \\
NOER & no-observed-effects-residue \\
R 2 & coefficient of determination \\
RSD & percent relative standard deviation \\
SE & standard error \\
THg & total mercury \\
WRST & Wrangell-St. Elias National Park and Preserve \\
ww & wet weight \\
yr & year or years \\
\hline
\end{tabular}




\title{
Mercury in Fishes from Wrangell-St. Elias National Park and Preserve, Alaska
}

\author{
By Brandon M. Kowalski, James J. Willacker, Jr., Christian E. Zimmerman, and Collin A. Eagles-Smith
}

\begin{abstract}
In this study, mercury $(\mathrm{Hg})$ concentrations were examined in fishes from Wrangell-St. Elias National Park and Preserve, Alaska, the largest and one of the most remote units in the national park system. The goals of the study were to (1) examine the distribution of $\mathrm{Hg}$ in select lakes of Wrangell-St. Elias National Park and Preserve; (2) evaluate the differences in $\mathrm{Hg}$ concentrations among fish species and with fish age and size; and (3) assess the potential ecological risks of $\mathrm{Hg}$ to park fishes, wildlife, and human consumers by comparing $\mathrm{Hg}$ concentrations to a series of risk benchmarks. Total $\mathrm{Hg}$ concentrations ranged from 17.9 to 616.4 nanograms per gram wet weight (ng/g ww), with a mean ( \pm standard error) of $180.0 \pm 17.9$ across the 83 individuals sampled. Without accounting for the effects of size, $\mathrm{Hg}$ concentrations varied by a factor of 10.9 across sites and species. After accounting for the effects of size, $\mathrm{Hg}$ concentrations were even more variable, differing by a factor of as much as 13.2 within a single species sampled from two lakes. Such inter-site variation suggests that site characteristics play an important role in determining fish $\mathrm{Hg}$ concentrations and that more intensive sampling may be necessary to adequately characterize $\mathrm{Hg}$ contamination in the park. Size-normalized $\mathrm{Hg}$ concentrations also differed among three species sampled from Tanada Lake, and $\mathrm{Hg}$ concentrations were strongly correlated with age. Furthermore, potential risks to park fish, wildlife, and human users were variable across lakes and species. Although no fish from two of the lakes studied (Grizzly Lake and Summit Lake) had Hg concentrations exceeding any of the benchmarks used, concentrations in Copper Lake and Tanada Lake exceeded conservative benchmarks for bird ( $90 \mathrm{ng} / \mathrm{g}$ ww in whole-body) and human (150 ng/g ww in muscle) consumption. In Tanada Lake, concentrations in most fishes also exceeded benchmarks for risk to moderate- and low-sensitivity avian consumers (180 and $270 \mathrm{ng} / \mathrm{g} \mathrm{ww}$ in whole-body, respectively), as well as the concentration at which Alaska State guidelines suggest atrisk groups limit fish consumption to 3 meals per week $(320 \mathrm{ng} / \mathrm{g})$. However, the relationship between $\mathrm{Hg}$ concentrations and fish size in Tanada Lake suggests that consumption of smaller-sized fishes could reduce $\mathrm{Hg}$ exposure in human consumers.
\end{abstract}

\section{Introduction}

Contamination of aquatic ecosystems with mercury $(\mathrm{Hg})$ is a widespread threat, affecting fish and wildlife, and posing risks for humans that consume fish (Scheuhammer and others, 2007). Atmospheric deposition of anthropogenic $\mathrm{Hg}$ emitted from fossil fuel combustion is among the primary pathways into aquatic ecosystems, although there also are many natural sources (for example, volcanoes and forest fires) that contribute to global background of $\mathrm{Hg}$ contamination (Driscoll and others, 2013). Within aquatic ecosystems, natural processes convert inorganic $\mathrm{Hg}$ to methylmercury (MeHg), a form of $\mathrm{Hg}$ that biomagnifies in aquatic food webs (Lavoie and others, 2013) and is highly toxic to fish and wildlife (Evers and others, 2007; Scheuhammer and others, 2007; Schwindt and others, 2008). 
The widespread distribution of atmospheric $\mathrm{Hg}$ places even remote environments at risk for $\mathrm{Hg}$ contamination. In particular, national parks in the United States often are remote and among the most protected public lands, yet are affected by anthropogenic Hg (Landers and others, 2008; Eagles-Smith and others, 2014). As a result, it is important to understand the extent and environmental consequences of $\mathrm{Hg}$ contamination in national parks. Moreover, $\mathrm{Hg}$ contamination has important implications for consumption of fish by subsistence users and park visitors who fish regularly in contaminated waters.

Wrangell-St. Elias National Park and Preserve (WRST) is an Alaska National Interest Lands Conservation Act national park, and as such, it provides access to subsistence harvest for many rural residents. A recent study of $\mathrm{Hg}$ in fish from 21 western national parks documented that some of the highest Hg concentrations were measured in fish from WRST (Eagles-Smith and others, 2014), with geometric mean values exceeding health criteria for the protection of fish-eating birds, mammals, and humans. However, it is unclear whether elevated Hg concentrations in fish from WRST are due to biological characteristics of the fish sampled (that is, age, size, species, trophic status, etc.) compared to local factors that enhance the availability of $\mathrm{Hg}$ within these food webs. Therefore, in order to better understand the distribution of $\mathrm{Hg}$ in WRST and the associated risk to aquatic communities and park visitors, $\mathrm{Hg}$ concentrations were measured in several fish species from four lakes in WRST, three of which were sampled previously by Eagles-Smith and others (2014). The primary objectives were to:

1. Determine the distribution of $\mathrm{Hg}$ concentrations in fishes among four lakes in WRST;

2. Evaluate the differences in fish $\mathrm{Hg}$ concentrations among fish species, and with fish age and size; and

3. Assess toxicological risk within the park by comparing $\mathrm{Hg}$ concentrations in fishes to a series of eight previously developed toxicological benchmarks for fish, fish-eating birds, and humans.

\section{Methods}

\section{Study Sites and Sample Collection}

Wrangell-St. Elias National Park and Preserve is the largest national park in the United States, spanning about 13.2 million acres and bounded on the south by the Gulf of Alaska coast (fig. 1). The park was established in 1980 and is managed to protect ecological integrity and heritage resources of south-central Alaska, while providing public use in a wild setting (Hood and others, 2006). The climate in the park is variable and extreme. Winter low temperatures can reach $-40{ }^{\circ} \mathrm{C}$ and summer high temperatures can reach $33{ }^{\circ} \mathrm{C}$ (Sousanes, 2012). Wrangell-St. Elias National Park and Preserve contains more than 96,000 acres of lakes and ponds, and more than $20,000 \mathrm{~km}$ of flowing waters. The park is divided into six major watersheds - the Bremner River, Chitina River, Copper River, Nabesna River, and White River drainages - and coastal streams (Weeks, 2003). The Copper River is the major river in the region, and the Bremner and Chitina Rivers flow westward into it and ultimately to the Gulf of Alaska. In contrast, the Nebesna and White Rivers are part of the Yukon River watershed, which drains into the Bering Sea. 


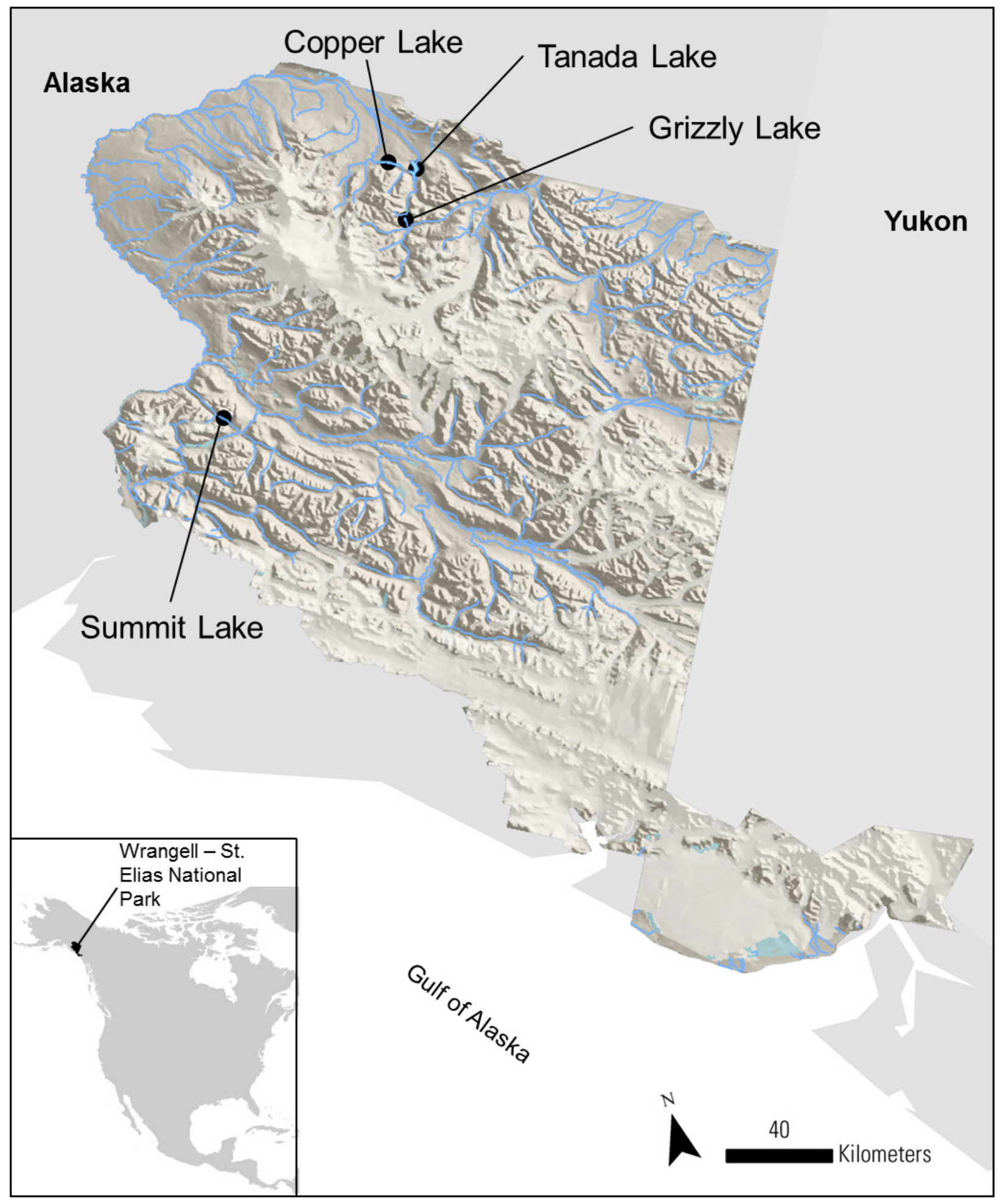

Figure 1. Schematic of four study lakes in Wrangell-St. Elias National Park and Preserve, Alaska. 
This study focuses on fish collected from four lakes in WRST (fig. 1; table 1). Tanada Lake is a large (2,718 acres), deep (53 m) lake in the Copper River headwaters at an elevation of $880 \mathrm{~m}$. Copper Lake, also is in the Copper River headwaters, $3 \mathrm{~km}$ west of Tanada Lake. Copper Lake has a surface area of 1,803 acres, with a maximum depth of $72 \mathrm{~m}$, and is at an elevation of $886 \mathrm{~m}$. Both Tanada lake and Copper lake contain burbot (Lota lota), lake trout (Salvelinus namaycush), Arctic grayling (Thymallus arcticus), round whitefish (Prosopium cylindraceum), longnose sucker (Catostomus catostomus), and sockeye salmon (Oncorhynchus nerka), which provide subsistence and recreational fishing opportunities (Weeks, 2003; Schwanke and McCormick, 2010; Kukkonen and Zimpelman, 2012). Copper Lake also has non-anadromous kokanee (Oncorhynchus nerka). Much less information is available for Grizzly and Summit Lakes. Grizzly Lake is at an elevation of 1,110 m within the Nabesna River drainage, and has a surface area of 252 acres and a maximum depth of $10 \mathrm{~m}$. Grizzly Lake is known to contain burbot and Arctic grayling. Summit Lake is about $130 \mathrm{~km}$ southwest of Tanada Lake at an elevation of $860 \mathrm{~m}$ in the Chitna River drainage of the Chugach Mountains, and contains introduced rainbow trout (Oncorhynchus mykiss).

National Park Service and Alaska Department of Fish and Game personnel collected fish from each of these four lakes in 2013. Fish were sampled using hoop nets, fyke nets, and hook and line. Four species of fish-Arctic grayling, burbot, lake trout, and rainbow trout-were collected. However, not all species were collected at all sites (table 1). After collection, fish were euthanized, placed on ice, measured (total length), wrapped in aluminum foil, individually labeled, frozen, and shipped to the laboratory for $\mathrm{Hg}$ analysis. After arrival at the laboratory, fish were stored at $-20^{\circ} \mathrm{C}$ until dissection and processing.

Table 1. Site locations and sample information for sites sampled in Wrangell-St. Elias National Park and Preserve, Alaska.

[SR: Size regression used-Y, yes; N, no]

\begin{tabular}{|c|c|c|c|c|c|c|c|}
\hline \multirow[b]{2}{*}{ Site and species } & \multicolumn{2}{|c|}{ Coordinates } & \multirow[b]{2}{*}{$\begin{array}{c}\text { Elevation } \\
\text { (meters) }\end{array}$} & \multicolumn{4}{|c|}{$\begin{array}{l}\text { Standard length } \\
\text { (millimeters) }\end{array}$} \\
\hline & Latitude & Longitude & & Number & Mean & Range & SR \\
\hline Copper Lake & 62.425 & -143.555 & 886 & & & & \\
\hline lake trout & & & & 15 & 378 & $297-454$ & $\mathrm{~N}$ \\
\hline Grizzly Lake & 62.222 & -143.365 & 1110 & & & & \\
\hline burbot & & & & 15 & 563 & $505-615$ & $\mathrm{~N}$ \\
\hline Summit Lake & 61.315 & -144.191 & 860 & & & & \\
\hline rainbow trout & & & & 15 & 309 & $200-388$ & $\mathrm{~N}$ \\
\hline Tanada Lake & 62.425 & -143.371 & 880 & & & & \\
\hline Arctic grayling & & & & 10 & 301 & $250-355$ & $\mathrm{Y}$ \\
\hline burbot & & & & 13 & 483 & $345-565$ & $\mathrm{Y}$ \\
\hline lake trout & & & & 15 & 413 & $330-470$ & $\mathrm{Y}$ \\
\hline
\end{tabular}




\section{Sample Preparation}

In the laboratory, we thawed fish at room temperature and then measured standard length (SL) to the nearest millimeter on a fish board, and mass to the nearest gram with a digital hand-held fish scale. Equations for converting standard length to total length for each species are provided in appendix 1. We excised 5-10 g of skinless axial muscle just anterior to the dorsal fin using acid-rinsed stainless-steel scalpels. After removal, muscle tissue was rinsed with deionized water, blotted dry with a lint-free wipe, and weighed to the nearest $0.0001 \mathrm{~g}$. The muscle tissue was then placed onto a clean aluminum weigh pan and dried in a convection oven at $50^{\circ} \mathrm{C}$ until a constant mass was achieved (typically 48 hours). Once dried, samples were stored in a desiccator until they cooled to room temperature. Finally, the dried muscle samples were weighed to the nearest $0.0001 \mathrm{~g}$ and ground to a fine powder using a ceramic mortar and pestle. Each mortar and pestle was rinsed with deionized water, dilute $\mathrm{HCl}$, and deionized water again between samples to avoid cross contamination

\section{Otolith Removal and Preparation}

Left and right sagittal otoliths were removed from each fish in order to estimate fish age. The shape and size of the otoliths varied among species; therefore, we used one of three otolith preparation methods depending on species. Rainbow trout otoliths were mounted flat, with the sulcus facing up on a clear glass microscope slide using cyanoacrylate adhesive. Excess otolith material was removed using 400- and (or) $600-\mu \mathrm{m}$ grit wet/dry sandpaper followed by polishing with a sequence of progressively finer lapping paper ranging from $30 \mu \mathrm{m}$ to $1 \mu \mathrm{m}$. Burbot otoliths were prepared using a "break and burn" method (Panfili and others, 2002; Committee of Age-Reading Experts, 2006) because they are very large and were difficult to polish using whole-otolith mounting methods. Briefly, burbot otoliths first were scored in the center using a scalpel, cracked in half, burned using a butane lighter, and polished using the sequential sanding-polishing methods described above. Finally, lake trout and Arctic grayling otoliths were mounted in thermoplastic cement (Crystalbond ${ }^{\mathrm{TM}} 509$, Ted Pella, Inc.), sectioned, and polished following the methods outlined in Black and others (2013) at the U.S. Geological Survey Alaska Science Center. In all cases, polishing was considered complete when the growth increments were clearly visible from the margins to the nucleus, and age was estimated by counting the sequence of transparent and opaque annuli along the plane from the nucleus to the margin. Age estimates were determined independently by two individual readers, and any discrepancies were resolved using a third independent estimate.

\section{Mercury Determination}

Total Hg (THg) concentrations were determined in dried axial muscle following U.S.

Environmental Protection Agency (EPA) method 7473 (2000) on a Milestone tri-cell DMA-80 Direct Mercury Analyzer ${ }^{\circledR}$ (Milestone Inc., Monroe, Connecticut). Total Hg concentration is an accepted proxy for $\mathrm{MeHg}$ concentrations because nearly all $\mathrm{Hg}$ in fish muscle is in the $\mathrm{MeHg}$ form (Hall and others, 1997). Quality-assurance measures included analysis of three certified reference materials (DORM4, TORT2, or DOLT4; National Research Council of Canada, Ottawa, Canada), two system and method blanks, and two duplicates per batch of 30 samples. Recoveries ( \pm standard error [SE]) averaged 97.5 \pm 2.4 percent $(\mathrm{n}=11)$ and $101.5 \pm 2.8$ percent $(\mathrm{n}=10)$ for certified reference materials and calibration checks, respectively. Absolute relative percent differences (RSD) for all duplicates averaged $2.3 \pm 0.7$ percent $(\mathrm{n}=11)$. 


\section{Statistical Analyses}

We conducted all statistical analyses of $\mathrm{Hg}$ concentrations on a dry weight (dw) basis in order to control for variability in tissue moisture. However, we also calculated wet weight (ww) concentrations using individual-based moisture content and present the data in wet weight to facilitate comparisons with other studies. Moisture content in the fish muscle ranged from 65.1 to 81.4 percent with a mean $( \pm \mathrm{SE})$ of $76.6 \pm 0.4$ percent.

Because fish size is often correlated with THg concentrations (Wiener and Spry, 1996), we first evaluated site- and species-specific length compared to THg relationships. Where appropriate, we sizenormalized $\mathrm{THg}$ concentrations of each fish to facilitate comparisons across sites and species. To make this determination, we evaluated the strength of each relationship based on their coefficient of determination $\left(\mathrm{R}^{2}\right)$ and Akaike's Information Criterion (AIC) for size compared to $\mathrm{THg}$ concentration ( $\log _{10}$-transformed) regression models from each species-site combination. No size normalization was conducted for models with $\mathrm{R}^{2}$ less than 0.2 . For regression models with $\mathrm{R}^{2}$ greater than 0.2 , AIC values were compared between the regression model and a null model. If the size by THg model had an AIC value of 2 units or lower (indicating a meaningful difference in model fit; Burnham and Anderson, 2010), size adjustments were made. We determined the sizes at which THg concentrations were normalized based on the size distribution of fish in each sample and the comparisons being made (see below). Mercury concentrations were size-normalized to median fish lengths by extracting the site- and species-specific regression model coefficients, and adding the individual residuals to the normalized predicted value.

Because we could not directly compare samples across all species and sites due to differences in species collected from each lake, we used a tiered statistical design to assess differences in $\mathrm{THg}$ concentrations among species within a lake, as well as among lakes for select species. For the withinlake assessment, Analysis of Covariance (ANCOVA) was used to compare size-normalized (350 mm SL) THg concentrations in Arctic grayling, burbot, and lake trout from Tanada Lake. In order to account for the effects of variable moisture content in the fish while facilitating intuitive interpretation, we converted the normalized THg concentrations (derived using dry weight data) to wet weight concentrations using percent moisture values for each fish and then included percent moisture in the ANCOVA model as a covariate. Thus, statistical results are presented on a wet weight basis, but adjusted for variable moisture content.

Because burbot and lake trout were both collected from more than one lake, ANCOVA was used to examine inter-lake variation in THg concentrations of burbot (from Grizzly and Tanada Lakes) and lake trout (from Copper and Tanada Lakes). Neither burbot from Grizzly Lake nor lake trout from Copper Lake had significant relationships between standard length and $\mathrm{THg}$ concentration that necessitated size adjustments of THg concentrations as described above. Conversely, THg increased with increasing standard length in both species from Tanada Lake. Therefore, burbot and lake trout from Tanada Lake were normalized to the median length of the species in Grizzly Lake (burbot, $550 \mathrm{~mm} \mathrm{SL}$ ) and Copper Lake (lake trout, $378 \mathrm{~mm} \mathrm{SL}$ ). Variation in moisture contents of individuals were accounted for by including percent moisture as a covariate in the ANCOVA model as described above. 


\section{Toxicological Risk Estimation}

In addition to comparing $\mathrm{THg}$ concentrations among lakes and species, we also evaluated the potential ecological risk of $\mathrm{Hg}$ exposure to fish, fish-eating birds, and humans by comparing $\mathrm{THg}$ concentrations to a series of eight previously developed toxicological benchmarks. Mercury concentrations in muscle were converted to whole-body concentrations (Peterson and others, 2005) in order to assess the toxicological risks of $\mathrm{Hg}$ to wildlife and fish, whereas muscle $\mathrm{Hg}$ concentrations were used to assess the toxicological risks to humans.

To assess potential toxicological effects of $\mathrm{Hg}$ to fish, we compared estimates of whole-body THg concentrations to a no-observed-effects-residue (NOER) of $200 \mathrm{ng} / \mathrm{g}$ ww (Beckvar and others, 2005) and a lowest-observed-effects-residue (LOER) of $300 \mathrm{ng} / \mathrm{g}$ ww (Sandheinrich and others, 2011). Tissue THg concentrations less than the NOER benchmark are not commonly associated with altered behavioral, development, growth, or reproduction of fishes, whereas THg concentrations in fishes greater than the LOER benchmark have been consistently associated with sublethal effects of $\mathrm{Hg}$, including changes in reproductive health (Sandheinrich and others, 2011). For fish-eating birds, wholebody $\mathrm{THg}$ concentrations were compared to three toxicological benchmarks representing risks to highly sensitive, moderately sensitive, and relatively insensitive species. Because robust estimates of dietary thresholds exist for only a few species, we used the threshold derived for a well-studied, moderately sensitive species, the common loon (Gavia immer; Scheuhammer and others, 2007; Kenow and others, 2008; Mitro and others, 2008; Scheuhammer and others, 2008; Heinz and others, 2009; Kenow and others, 2011), as a baseline. A review of field and laboratory studies on $\mathrm{Hg}$ toxicity in common loons found that $\mathrm{Hg}$ concentrations greater than $180 \mathrm{ng} / \mathrm{g}$ ww in prey fish were associated with significant reductions in reproductive success of wild loons (Depew and others, 2012). We used this concentration as the benchmark for risk to moderately sensitive avian consumers, and evaluated the likely range of risk to more-or-less-sensitive avian consumers by scaling this threshold by \pm 50 percent. Thus, risk to avian consumers was assessed by comparing $\mathrm{Hg}$ concentrations in whole-body fish to 90 (high sensitivity), 180 (moderate sensitivity), and $270 \mathrm{ng} / \mathrm{g}$ ww (low sensitivity) benchmarks. For human health risk, muscle $\mathrm{THg}$ concentrations were compared to three fish consumption guidelines recommended by the Alaska Department of Health and Social Services (AK-DHSS) to protect women who are or can become pregnant, nursing mothers, and young children (aged 12 years or younger; Verbrugge, 2007). These guidelines $(150,320$, and $640 \mathrm{ng} / \mathrm{g}$ ww in fish muscle) correspond to the concentrations at which AK-DHSS recommends at-risk groups limit fish consumption to 4, 3, and 1 meal per week, respectively, and aim to balance the risks and health benefits of fish consumption. 
Comparisons were made to these benchmarks using two approaches. First, we compared raw (that is, not size-normalized), whole-body (fish and avian benchmarks) or muscle (human benchmarks) $\mathrm{THg}$ concentrations to each of the eight benchmarks and enumerated the proportion of individuals of each species in each lake that exceeded the benchmarks. This approach provides a coarse overview of risk for each species and site, but does not account for the effects of fish size on risk in those populations with size-THg relationships. Therefore, the second approach assessed the proportion of individuals that would exceed each benchmark over the range of standard lengths observed in the sample. To accomplish this comparison, site- and species-specific length-THg relationships were used to model risk at 1-mm size increments over the entire range of lengths observed in the sample. Effectively, all fish in a sample were normalized to the size of the smallest fish, then in 1-mm increments until the size of the largest fish in a sample was reached. At each of these size increments, the proportion of fish exceeding each benchmark was enumerated. Uncertainty in these size-specific risk estimates was preserved by comparing the bounds of a 95-percent prediction interval for each fitted value to the benchmarks. Thus, the resulting graphics show the estimated proportion of fish in a population that would exceed a threshold at a given size and can be used to identify the size of fish at which some threshold of acceptable risk is exceeded.

\section{Results}

We analyzed THg concentrations in a total of 83 fish from the four study lakes in $2013-15$ lake trout from Copper Lake, 15 burbot from Grizzly Lake, and 15 rainbow trout from Summit Lake, as well as 15 lake trout, 10 Arctic grayling, and 13 burbot from Tanada Lake. Total $\mathrm{Hg}$ concentrations ranged from 17.9 to $616.4 \mathrm{ng} / \mathrm{g}$ ww across all sites and species, with a mean $( \pm \mathrm{SE}) \mathrm{THg}$ concentration of 180.0 $\pm 17.9 \mathrm{ng} / \mathrm{g}$ ww. Site- and species-specific mean THg concentrations were highest in burbot $(382.5 \pm 40.3$ ng/g ww) and lake trout from Tanada Lake (371.7 $\pm 26.8 \mathrm{ng} / \mathrm{g} \mathrm{ww})$, followed by lake trout from Copper Lake $(144.7 \pm 6.7 \mathrm{ng} / \mathrm{g} \mathrm{ww})$, Arctic grayling from Tanada Lake (108.6 $\pm 9.2 \mathrm{ng} / \mathrm{g} \mathrm{ww})$, burbot from Grizzly Lake (40.6 $\pm 4.4 \mathrm{ng} / \mathrm{g} \mathrm{ww})$, and rainbow trout from Summit Lake (35.2 $\pm 3.3 \mathrm{ng} / \mathrm{g} \mathrm{ww}$; fig. 2). However, THg concentrations were correlated with fish size in some populations (fig. 3), necessitating size-adjustment of $\mathrm{THg}$ concentrations in order to make accurate comparisons. Similarly, some, but not all, populations had significant positive relationships between age and $\mathrm{THg}$ concentration (fig. 4). Age generally was a better predictor of fish $\mathrm{THg}$ concentrations than length (table 2). Total $\mathrm{Hg}$ concentrations in Tanada Lake Arctic grayling $\left(\mathrm{R}^{2}=0.55, \mathrm{P}=0.0042\right)$ and lake trout $\left(\mathrm{R}^{2}=0.72, \mathrm{P}<0.0001\right)$ were correlated with age, whereas burbot from Tanada $\left(\mathrm{R}^{2}=0.37, \mathrm{P}=0.0230\right)$ and Grizzly Lakes $\left(\mathrm{R}^{2}=0.31, \mathrm{P}=0.0247\right)$ had weaker correlations. There was no relationship between age and $\mathrm{THg}$ concentration in lake trout from Copper Lake $\left(\mathrm{R}^{2}=-0.01, \mathrm{P}=0.4354\right)$ or rainbow trout from Summit Lake $\left(\mathrm{R}^{2}=-0.05, \mathrm{P}=0.5449\right)$. Length by age plots indicated that fish size in several populations approached an asymptote of maximum size in the oldest individuals (fig. 5). 


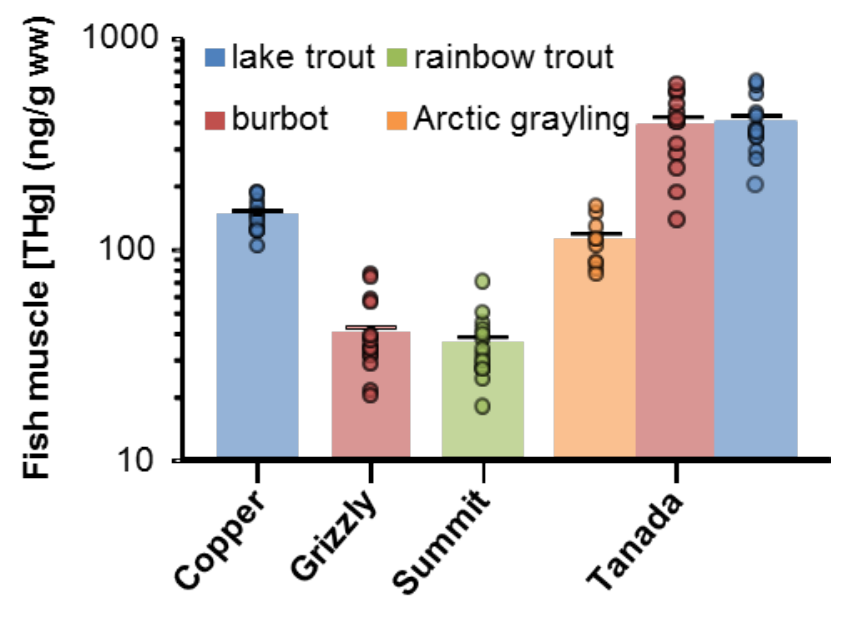

Figure 2. Arithmetic-mean total mercury concentrations (THg, in nanograms per gram wet weight [ng/g ww]) \pm 1 standard error in fish species collected from four lakes in Wrangell-St. Elias National Park and Preserve, Alaska.

Table 2. Comparison of coefficient of determination $\left(R^{2}\right)$ and $P$-values between mercury-age and mercury-length regressions from fish sampled in Wrangell-St. Elias National Park and Preserve, Alaska.

\begin{tabular}{lcccc}
\hline \multicolumn{1}{c}{ Site and species } & \multicolumn{2}{c}{ Age } & \multicolumn{2}{c}{ Size } \\
& $\mathbf{R}^{2}$ & P-value & $\mathbf{R}^{2}$ & P-value \\
\hline $\begin{array}{l}\text { Copper Lake } \\
\quad \text { lake trout }\end{array}$ & -0.01 & 0.4354 & -0.08 & 0.9412 \\
$\begin{array}{l}\text { Grizzly Lake } \\
\quad \text { burbot }\end{array}$ & 0.31 & 0.0247 & 0.11 & 0.1218 \\
$\begin{array}{l}\text { Summit Lake } \\
\quad \text { rainbow trout }\end{array}$ & & & & \\
$\quad \begin{array}{l}\text { Tanada Lake } \\
\quad \text { Arctic grayling }\end{array}$ & -0.05 & 0.5449 & 0.04 & 0.2384 \\
$\quad$ burbot & & & & \\
$\quad$ lake trout & 0.55 & 0.0042 & 0.36 & 0.0388 \\
\hline
\end{tabular}




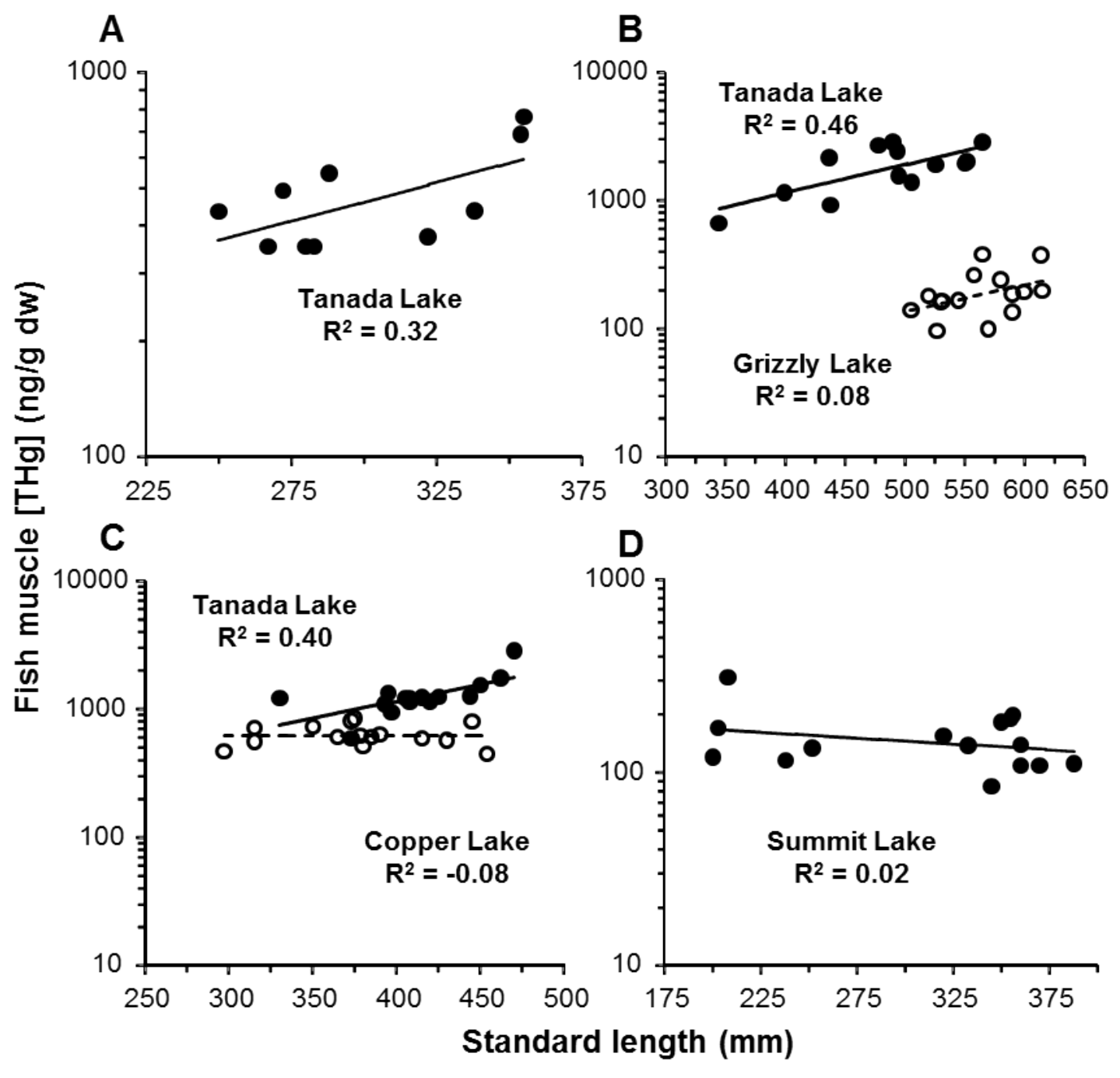

Figure 3. Linear relationships between standard length (in millimeters, [mm]) and total mercury concentrations (THg, in nanograms per gram dry weight [ng/g dw]) in fish muscle of (A) Arctic grayling, (B) burbot, (C) lake trout, and (D) rainbow trout sampled from Wrangell-St. Elias National Park and Preserve, Alaska. 


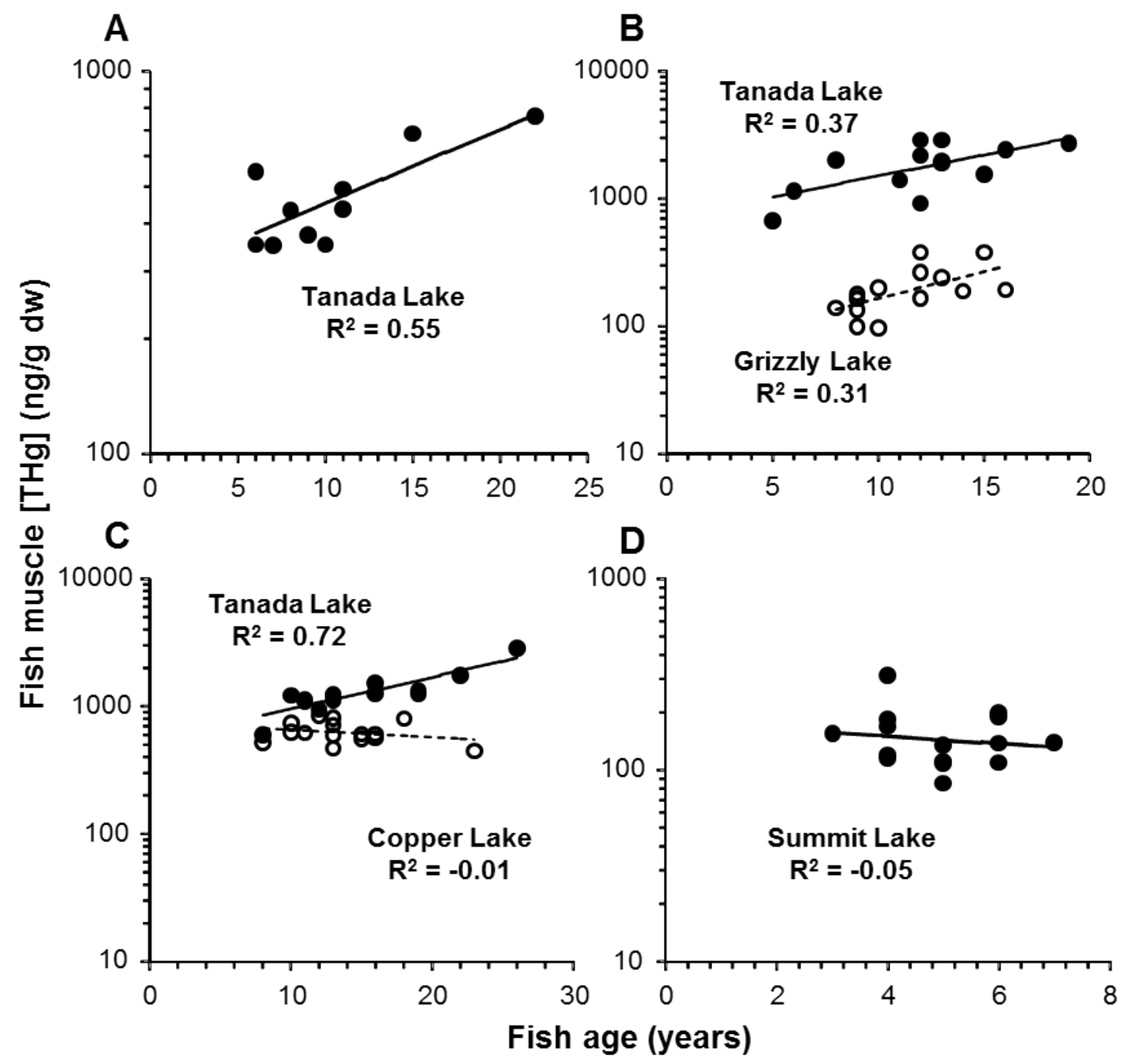

Figure 4. Linear relationships between fish age (in years) and total mercury concentrations (THg, in nanograms per gram dry weight [ng/g dw]) in fish muscle of (A) Arctic grayling, (B) burbot, (C) lake trout, and (D) rainbow trout sampled from Wrangell-St. Elias National Park and Preserve, Alaska. 


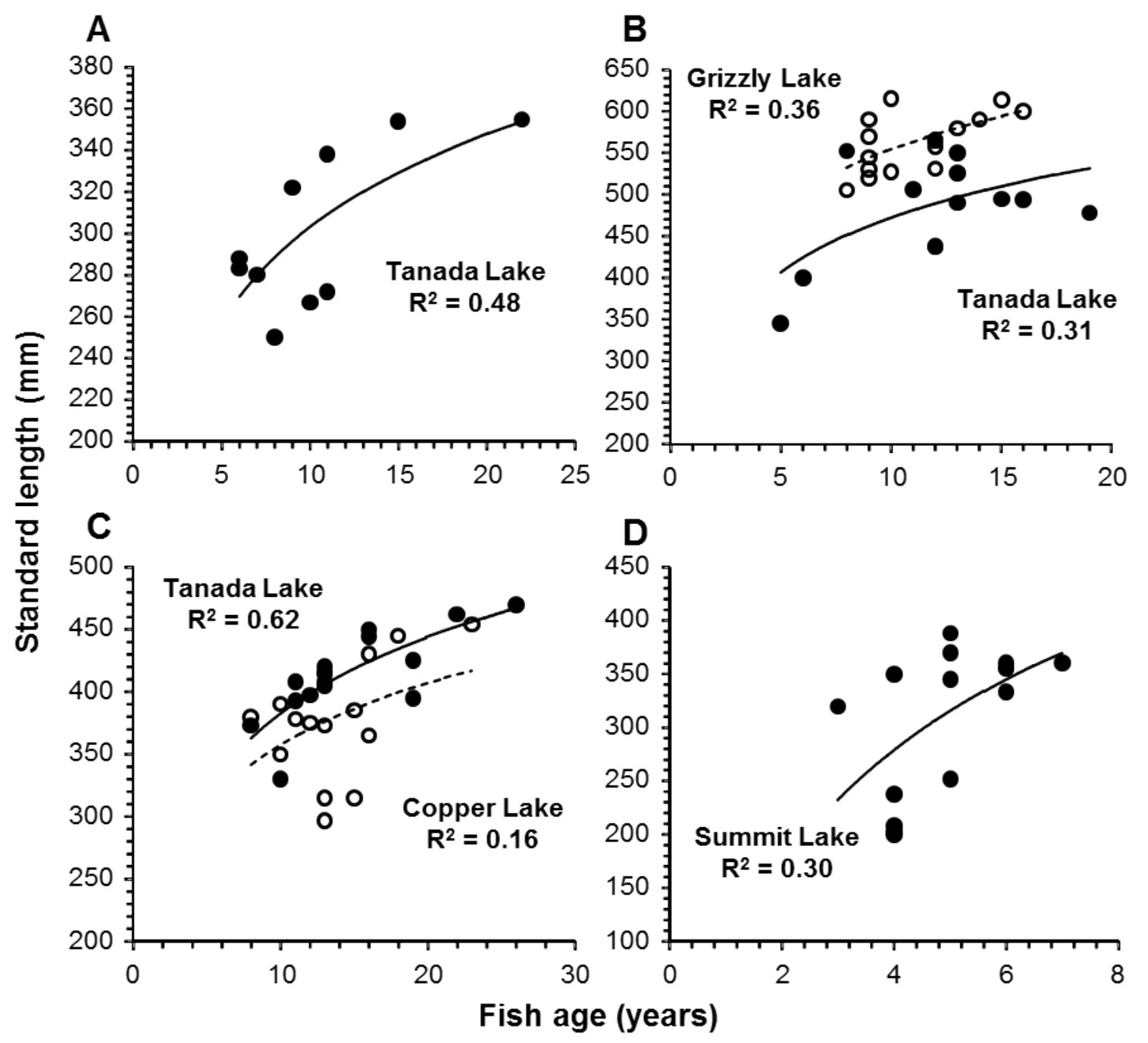

Figure 5. Logarithmic relationships between fish age (in years) and standard length (in millimeters [mm]) of (A) Arctic grayling, (B) burbot, (C) lake trout, and (D) rainbow trout sampled from Wrangle-St. Elias National Park and Preserve, Alaska. 


\section{Species Comparisons}

Tanada Lake was the only site from which more than one species was collected; therefore, species comparisons were limited to Tanada Lake. After size -normalizing THg concentrations in all fish from Tanada Lake to $350 \mathrm{~mm} \mathrm{SL}$, we found significant differences in the THg concentrations among the species (fig. 6; $\mathrm{F}_{2,37}=10.08, \mathrm{P}=0.0004$ ). Concentrations were highest in lake trout (253.2 $\pm 24.6 \mathrm{ng} / \mathrm{g} \mathrm{ww})$, and lowest in Arctic grayling (133.2 $\pm 13.5 \mathrm{ng} / \mathrm{g} \mathrm{ww})$. Burbot $\mathrm{THg}$ concentrations were intermediate $(184.6 \pm 19.0 \mathrm{ng} / \mathrm{g} \mathrm{ww})$ between the other two species, but were not statistically different from either lake trout $(\mathrm{P}=0.15)$ or grayling $(\mathrm{P}=0.08)$.

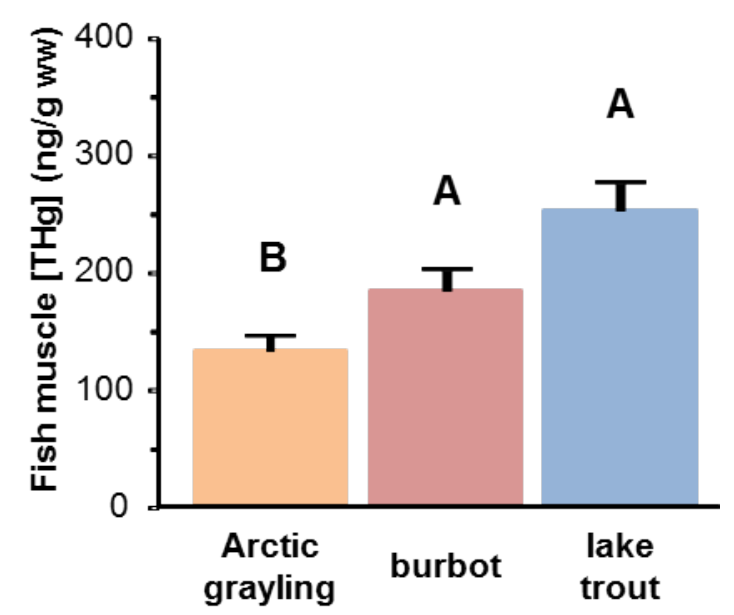

Figure 6. Back-transformed least-square mean total mercury concentrations (THg, in nanograms per gram wet weight [ng/g ww]) in muscle of fishes from Tanada Lake, Wrangell-St. Elias National Park and Preserve, Alaska. All concentrations are size-normalized to 350 millimeters standard length and error bars are standard errors estimated using the delta method. 


\section{Site Comparisons}

We observed inter-lake differences in the THg concentrations of lake trout and burbot that were each sampled from two lakes (burbot, $\mathrm{F}_{1,27}=112.82, \mathrm{P}<0.0001$; lake trout, $\mathrm{F}_{1,29}=31.93, \mathrm{P}<0.0001$; fig. 7). Size-normalized (550 mm SL) THg concentrations in burbot were higher in Tanada Lake (535.2 $\pm 34.7 \mathrm{ng} / \mathrm{g} \mathrm{ww})$ than in Grizzly Lake $(40.6 \pm 31.1 \mathrm{ng} / \mathrm{g} \mathrm{ww})$, despite similar median ages in the two populations (Tanada Lake=12 yr; Grizzly Lake=10 yr; fig. 5). Likewise, size-normalized (378 mm SL) THg concentrations in lake trout were higher in Tanada Lake $(302.9 \pm 14.4 \mathrm{ng} / \mathrm{g} \mathrm{ww})$ than in Copper Lake (138.7 $\pm 25.2 \mathrm{ng} / \mathrm{g} \mathrm{ww})$, even though the median age of both populations was $13 \mathrm{yr}$ (fig. 5).

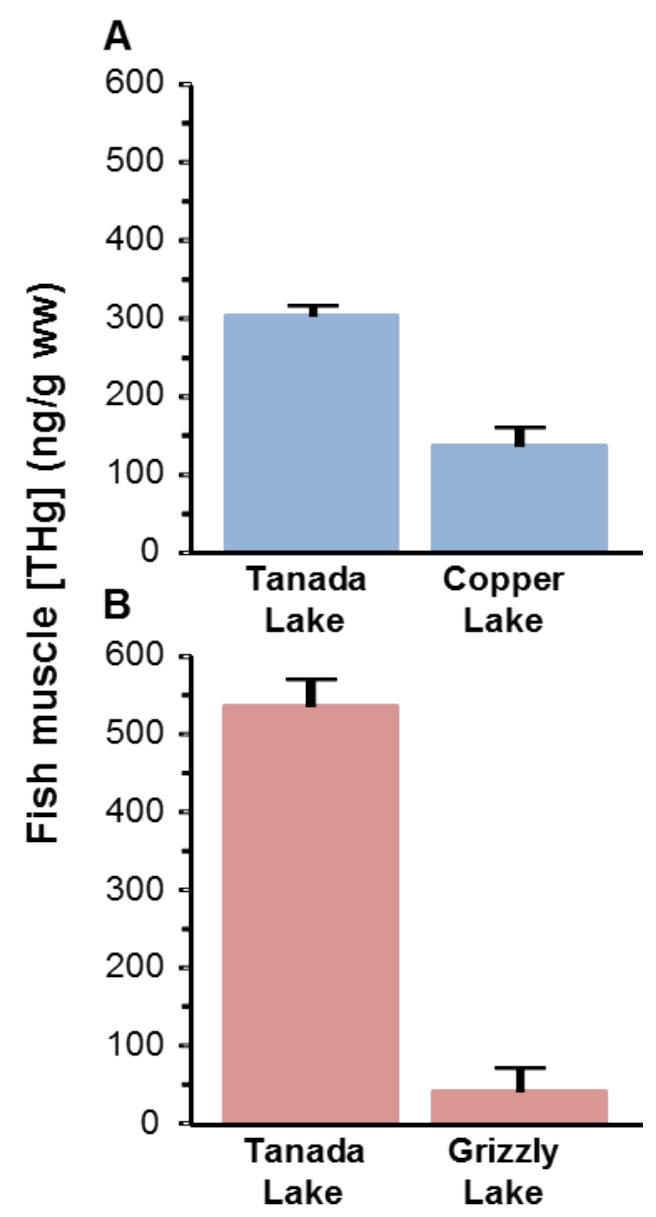

Figure 7. Back-transformed least-square mean total mercury concentrations (THg, in nanograms per gram wet weight [ng/g ww]) in muscle of $(A)$ lake trout, and $(B)$ burbot from lakes in Wrangell-St. Elias National Park and Preserve, Alaska. Lake trout from Tanada Lake were size-normalized to the median length of Copper Lake lake trout (378 millimeters). Burbot from Tanada Lake were size-normalized to the median length of Grizzly Lake burbot (550 millimeters). Mercury concentrations for lake trout from Copper Lake and burbot from Grizzly Lake are geometric means. Error bars are standard errors estimated using the delta method. 


\section{Toxicological Risks}

\section{Fish Risk}

We first assessed risk to fishes based on the proportion of non-size-normalized, whole-body THg concentrations that exceeded the selected toxicological benchmarks. Across all sites and species, 24 percent of fish sampled (20 individuals) had whole-body $\mathrm{THg}$ concentrations exceeding the NOER benchmark for which $\mathrm{Hg}$ exposure may affect fish health (200 ng/g ww; table 3), and 6 percent (5 individuals) had concentrations exceeding the LOER benchmark (300 ng/g ww; table 3). All fish exceeding the NOER benchmark were from Tanada Lake, where 53 percent of the fish sampled (20 individuals) exceeded the benchmark. On a species specific-basis, in Tanada Lake, none of the Arctic grayling, 62 percent of the burbot ( 8 individuals), and 80 percent of the lake trout ( 12 individuals) exceeded the $200 \mathrm{ng} / \mathrm{g}$ NOER benchmark. Across all species, 13 percent of fish ( 5 individuals) from Tanada Lake exceeded the LOER benchmark, comprised of 23 percent of burbot ( 3 individuals) and 13 percent of lake trout ( 2 individuals), and no Arctic grayling.

Table 3. Percentage of fish from four lakes in Wrangell-St. Elias National Park and Preserve, Alaska, with raw (that is, non-size corrected) total mercury concentrations exceeding defined toxicity benchmarks for fish, avian, and human risk.

[Fish and avian benchmarks are based on wet weight whole-body concentrations whereas human benchmarks are based on wet weight concentrations in fish muscle]

\begin{tabular}{|c|c|c|c|c|c|c|c|c|}
\hline \multirow[b]{2}{*}{ Site and species } & \multicolumn{2}{|c|}{ Fish toxicity } & \multicolumn{3}{|c|}{ Bird toxicity } & \multicolumn{3}{|c|}{ Human consumption ${ }^{c}$} \\
\hline & $\begin{array}{c}\text { NOERa } \\
(200 \mathrm{ng} / \mathrm{g})\end{array}$ & $\begin{array}{l}\text { LOERb }^{b} \\
(300 \\
\mathrm{ng} / \mathrm{g})\end{array}$ & $\begin{array}{l}\text { High } \\
\text { sensitivityy } \\
(90 \mathrm{ng} / \mathrm{g})\end{array}$ & $\begin{array}{c}\text { Mod. } \\
\text { sensitivity. } \\
(180 \\
\mathrm{ng} / \mathrm{g})\end{array}$ & $\begin{array}{c}\text { Low } \\
\text { sensitivity. } \\
(270 \\
\text { ng/g) }\end{array}$ & $\begin{array}{c}\text { Unrestricted } \\
\text { consumption } \\
(150 \mathrm{ng} / \mathrm{g})\end{array}$ & $\begin{array}{c}4 \text { Meals } \\
\text { per } \\
\text { week } \\
(320 \\
\text { ng/g })\end{array}$ & $\begin{array}{c}2 \text { Meal } \\
\text { per week } \\
(640 \\
\mathrm{ng} / \mathrm{g})\end{array}$ \\
\hline Across All Sites & 24 & 6 & 45 & 25 & 7 & 41 & 25 & -- \\
\hline $\begin{array}{l}\text { Copper Lake } \\
\text { lake trout }\end{array}$ & -- & -- & 53 & -- & -- & 40 & -- & -- \\
\hline $\begin{array}{c}\text { Grizzly Lake } \\
\text { burbot } \\
\text { Summit Lake }\end{array}$ & -- & -- & -- & -- & -- & -- & -- & -- \\
\hline rainbow trout & -- & -- & -- & -- & -- & -- & -- & -- \\
\hline Tanada Lake & 53 & 13 & 76 & 55 & 16 & 74 & 55 & -- \\
\hline Arctic grayling & -- & -- & 20 & -- & -- & 10 & -- & -- \\
\hline burbot & 62 & 23 & 92 & 69 & 31 & 92 & 62 & -- \\
\hline lake trout & 80 & 13 & 100 & 80 & 13 & 100 & 87 & -- \\
\hline
\end{tabular}


We also examined risk over the size range of fish sampled in order to account for the effects of size and age on THg concentrations. These size-specific risk models predicted that Arctic grayling would not exceed the $200 \mathrm{ng} / \mathrm{g}$ ww NOER or the $300 \mathrm{ng} / \mathrm{g}$ ww LOER benchmarks at any size sampled (fig. 8). Conversely, burbot and lake trout were predicted to first exceed the NOER toxicological benchmark at 370 and $356 \mathrm{~mm} \mathrm{SL}$, respectively, with greater than or equal to 50 percent of each population expected to exceed this threshold at 492 and $398 \mathrm{~mm}$ SL. One-hundred percent of burbot and lake trout with greater than 559 and $470 \mathrm{~mm} \mathrm{SL}$, respectively, were predicted to exceed the NOER (appendix 2). Burbot and lake trout first exceeded the LOER benchmark at 463 and $432 \mathrm{~mm}$ SL, respectively, and both plateaued at about 46 percent of the population exceeding the benchmark at 565 and $470 \mathrm{~mm}$ SL, respectively (fig. 8).

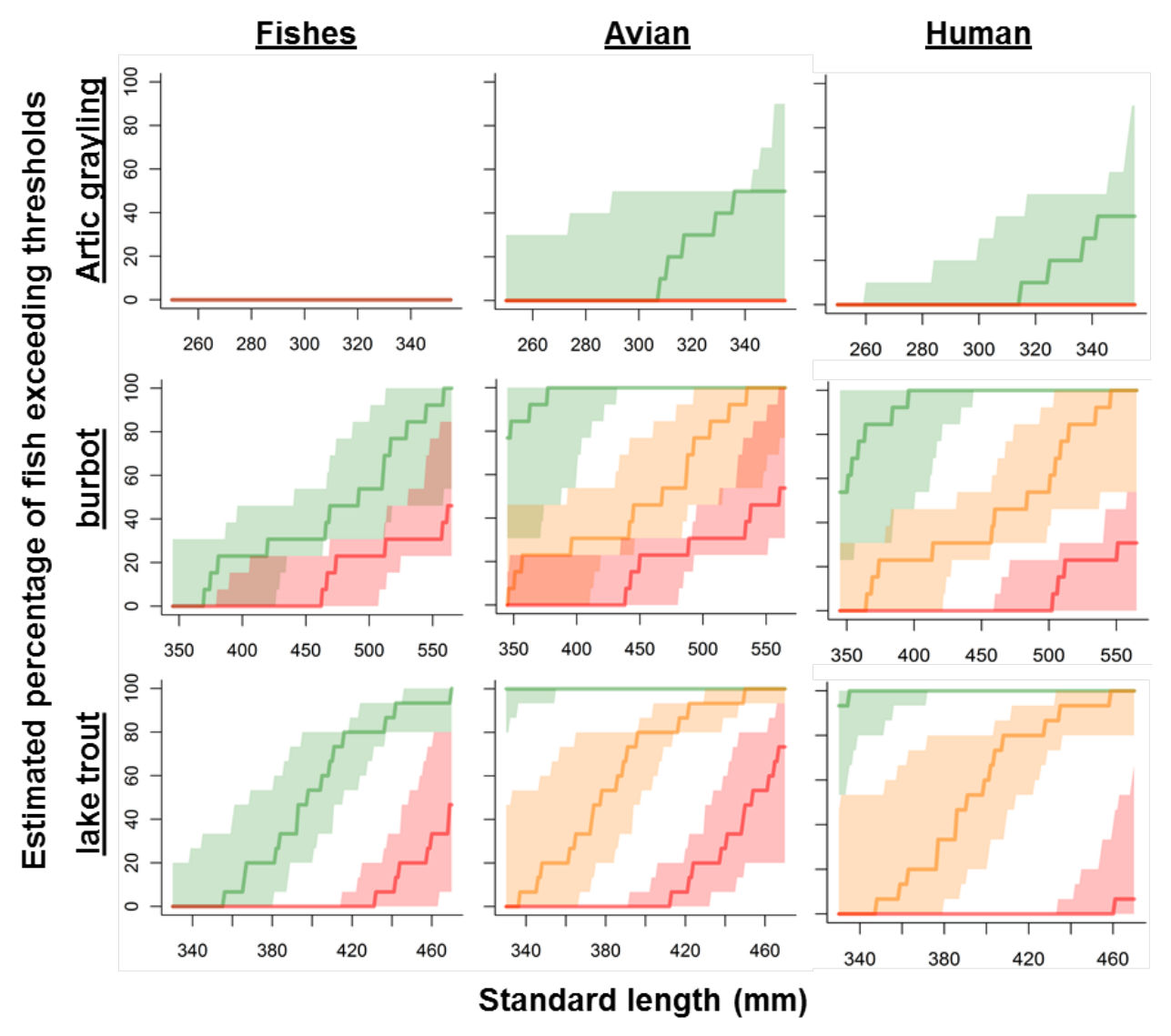

Figure 8. Modeled relationship between fish size and the percentage of Arctic grayling, burbot, and lake trout from Tanada Lake, Wrangell-St. Elias National Park and Preserve, Alaska, that exceed defined toxicological benchmarks for fishes, avian, and human consumers. Fishes: Percentage of whole-body total mercury concentrations at the sampled size range that exceed benchmarks for a generic no-observed-effects residue (green; $200 \mathrm{ng} / \mathrm{g} \mathrm{ww}$ ), and lowest-observed-effects residue (red; 300 nanograms per gram wet weight [ng/g ww]) for fish health. Avian: Percentage of whole-body total mercury concentrations at the sampled size range that exceed dietary toxicity benchmarks for piscivorous birds that can be classified as high (green; $90 \mathrm{ng} / \mathrm{g} \mathrm{ww}$ ), medium (orange; $180 \mathrm{ng} / \mathrm{g} \mathrm{ww}$ ), or low (red; $270 \mathrm{ng} / \mathrm{g} \mathrm{ww}$ ) sensitivity. Human: Percentage of muscle total mercury concentrations exceeding the Alaska Department of Health and Social Services guidelines at which they recommend women of childbearing age and children younger than 12 years of age consume no more than 4 meals per week (green; $150 \mathrm{ng} / \mathrm{g} \mathrm{ww}$ ), 3 meals per week (orange; $320 \mathrm{ng} / \mathrm{g} \mathrm{ww}$ ), or 2 meals per week (red; 640 ng/g ww). 


\section{Avian Risk}

Across all sites, 45 percent of fish sampled (37 individuals) had THg concentrations greater than the proximate benchmark for $\mathrm{Hg}$ effects to highly sensitive avian piscivores $(90 \mathrm{ng} / \mathrm{g} \mathrm{ww}), 25$ percent (21 individuals) had tissue concentrations greater than the benchmark for moderate-sensitivity species (180 ng/g ww), and 7 percent (6 individuals) had concentrations greater than the benchmark for lowsensitivity species (270 ng/g ww; table 3). Whole-body THg concentrations exceeded the highsensitivity benchmark in lake trout from Copper Lake (53 percent [8 individuals] of fish) and in all three fish species from Tanada Lake (Arctic grayling — 20 percent [2 individuals]; burbot—92 percent [12 individuals]; lake trout-100 percent [15 individuals]). Only burbot and lake trout from Tanada Lake exceeded the moderate-sensitivity benchmark ( 69 and 80 percent [ 9 and 12 individuals] for burbot and lake trout, respectively) and low-sensitivity benchmark (31 and 13 percent [4 and 2 individuals], respectively; table 3).

Size-specific risk models estimated that whole-body THg concentrations exceeded the highsensitivity benchmark for all three species in Tanada Lake (fig. 8). Arctic grayling first exceeded the high-sensitivity benchmark at $308 \mathrm{~mm} \mathrm{SL}$, with greater than or equal to 50 percent of the population expected to exceed this benchmark at $336 \mathrm{~mm}$ SL (appendix 2). Seventy-six percent of burbot exceeded the high-sensitivity benchmark at $345 \mathrm{~mm} \mathrm{SL}$, the lowest length observed for this species in Tanada Lake. One hundred percent of the burbot exceeded the high-sensitivity avian benchmark at $377 \mathrm{~mm} \mathrm{SL}$, and all lake trout exceeded this benchmark at the lowest observed length of $330 \mathrm{~mm}$. None of the Arctic grayling were modeled to exceed the moderate- or low-sensitivity benchmarks within the size range sampled. Burbot first exceeded the moderate-sensitivity benchmark at $346 \mathrm{~mm} \mathrm{SL}$, greater than or equal to 50 percent of the population exceeded at $468 \mathrm{~mm} \mathrm{SL}$, and 100 percent at $535 \mathrm{~mm} \mathrm{SL}$. Lake trout from Tanada Lake were first modeled to exceed the moderate-sensitivity benchmark at $337 \mathrm{~mm}$ SL, with greater than or equal to 50 percent and 100 percent exceeding this threshold at 378 and $450 \mathrm{~mm} \mathrm{SL}$, respectively. Burbot and lake trout first exceeded the low-sensitivity benchmark at 439 and $413 \mathrm{~mm}$ SL, respectively. Greater than 50 percent of burbot and lake trout whole-body $\mathrm{THg}$ concentrations exceeded the low sensitivity threshold at 561 and $454 \mathrm{~mm} \mathrm{SL}$, respectively (appendix 2).

\section{Human Consumption Risk}

For the raw, unadjusted data across all sites, 41 percent of the fish sampled (34 individuals) had THg concentrations in their muscle that exceeded the AK-DHSS unrestricted human consumption guideline (150 ng/g ww in fish muscle), 25 percent of the fish sampled (21 individuals) exceeded the 4meal-per-week AK-DHSS guideline (320 ng/g ww), and none of the fish had concentrations greater than the guideline at which AK-DHSS recommends consumption be limited to 1 meal per week. Forty percent of lake trout ( 6 individuals) from Copper Lake exceeded the unrestricted consumption guidance benchmark, although no fish from Copper Lake were determined to have muscle $\mathrm{THg}$ concentrations greater than the 4-meal-per-week guideline. Ten percent of Arctic grayling (1 individual) from Tanada Lake exceeded the AK-DHSS unrestricted consumption guideline, whereas none exceeded the 4-mealper-week guideline. All lake trout and 92 percent of burbot (12 individuals) from Tanada Lake exceeded the unrestricted consumption guideline, whereas 87 percent of lake trout (13 individuals) and 62 percent of burbot ( 8 individuals) exceeded the 4-meal-per-week guideline. 
Total mercury muscle concentrations in fish sampled from Tanada Lake were modeled across the observed size range to assess the risks of human consumption (fig. 8). Arctic grayling were first modeled to exceed the AK-DHSS unrestricted consumption guideline at $315 \mathrm{~mm}$ SL, but no individuals were modeled to exceed the 4- or 2-meal-per week-guidelines at any size sampled. Fifty-four and 93 percent of burbot and lake trout, respectively, exceeded the AK-DHSS unrestricted consumption guideline at the smallest sizes observed (345 and $330 \mathrm{~mm} \mathrm{SL}$, respectively; appendix 2). Models estimated that burbot and lake trout would first exceed the AK-DHSS 4-meal-per-week guideline at 365 and $348 \mathrm{~mm} \mathrm{SL}$, respectively, and that 50 percent or more fish exceeded this benchmark at 484 and 391 $\mathrm{mm}$ SL, respectively. One-hundred percent of burbot greater than $546 \mathrm{~mm}$ SL and lake trout greater than $459 \mathrm{~mm}$ SL were modeled to exceed the AK-DHSS 4-meal-per-week guideline. Some of the burbot greater than $503 \mathrm{~mm} \mathrm{SL}$ and lake trout greater than $461 \mathrm{~mm}$ SL were modeled to exceed the AKDHSS 2-meal-per-week guideline, although they were never more than 30 percent of the population (fig. 8; appendix 2).

\section{Discussion}

Results of this study indicate that $\mathrm{Hg}$ bioaccumulation and risk to remote aquatic ecosystems within WRST are highly variable among lakes and among species within a lake. Total $\mathrm{Hg}$ concentrations in individual fish ranged by an order of magnitude across the 83 individuals analyzed, with the highest concentrations exceeding $600 \mathrm{ng} / \mathrm{g}$ ww. Even within a single species, size-normalized $\mathrm{THg}$ concentrations differed among lakes. THg concentrations in lake trout from Tanada Lake were 2.2 times higher than lake trout from Copper Lake, and concentrations in burbot from Tanada Lake were 13.2 times higher than burbot from Grizzly Lake. Furthermore, some of the THg concentrations in fish, particularly from Tanada Lake, were high enough to be of concern for wildlife and humans that consume them. However, the relationship between THg concentrations and fish size in Tanada Lake suggests that $\mathrm{Hg}$ exposure in human consumers could be reduced by harvesting small-sized fishes.

Although fish THg concentrations varied substantially among sites, they generally are comparable to those measured in these species from other studies in remote northern habitats. For example, $\mathrm{THg}$ concentrations in lake trout and Arctic grayling averaged between 58 and $216 \mathrm{ng} / \mathrm{g} \mathrm{ww}$, and 54 to $112 \mathrm{ng} / \mathrm{g}$ ww, respectively, in four lakes in Arctic Alaska (Allen-Gil and others, 1997). These concentrations are similar to those that we measured in fish from Copper, Grizzly, and Summit Lakes, but are considerably less than the mean values from Tanada Lake. Similarly, mean $\mathrm{Hg}$ concentrations for lake trout (180 ng/g ww) and burbot (150 ng/g ww) from Great Slave Lake, Canada (Evans and others, 2013) were comparable to those that we measured in Copper and Grizzly Lakes, but are considerably less than the mean values from Tanada Lake. It is unclear why THg concentrations in fish from Tanada Lake were elevated in comparison to the other lakes, but could be related to lake or catchment characteristics that facilitate higher bioaccumulation or biomagnification of $\mathrm{Hg}$ in this system, or to marine-derived sources associated with the return of anadromous fish since only Tanada Lake has substantial salmon returns each year (Written Communication, Dave Sarafin, National Park Service, 5/8/2014). Many factors are known to influence these processes, including $\mathrm{Hg}$ inputs, $\mathrm{MeHg}$ production, and food web processes that regulate the flow of $\mathrm{Hg}$ through systems. A primary source of Hg inputs into WRST lakes likely is atmospheric deposition (Jaffe and others, 2008; Durnford and others, 2010; Phillips and others, 2011). Despite the close proximity of three of the lakes assessed in this study, the surface area of Tanada Lake (2,718 acres) is 1.5 times greater than the surface area of Copper Lake (1,830 acres) and 11 times greater than the surface area of Grizzly Lake (252 acres). Additionally, the surface area of Tanada Lake catchment basin $(84,830$ acres) is 3 times greater than that of Copper Lake (26,804 acres), and 47 times greater than that of Grizzly Lake (1,790 acres). Therefore, even if the 
delivery rates per unit area are similar among the three lakes, the substantially larger lake and catchment size likely results in higher total atmospheric $\mathrm{Hg}$ loading in Tanada Lake relative to Copper Lake, and in Copper Lake relative to Grizzly Lake. Hg concentrations in fish follow these trends, suggesting that further investigation of the influence of catchment drivers is warranted. Differences in $\mathrm{Hg}$ concentrations among the four lakes also could reflect varying geologic conditions, such as differing bedrock composition or glacial activity in the upstream watersheds, a hypothesis that could be assessed by measuring $\mathrm{Hg}$ concentrations in sediment and water inputs to the lakes.

Although $\mathrm{Hg}$ inputs play a role in determining $\mathrm{Hg}$ concentrations in fish, the biogeochemical factors that control $\mathrm{MeHg}$ production also are key drivers of $\mathrm{Hg}$ bioaccumulation in food webs (Ulrich and others, 2001; Benoit and others, 2003). Thus, lake and watershed characteristics, including the presence of wetlands, high-quality organic matter inputs, and low $\mathrm{pH}$, facilitate $\mathrm{Hg}$ methylation and, thus, are often important drivers of $\mathrm{Hg}$ bioaccumulation in fish (Watras and others, 1998; Snodgrass and others, 2000; Greenfield and others, 2001; Wiener and others, 2006). In order to understand the role methylation plays in generating the variable THg concentrations measured in WRST fish, future research should include abiotic and low trophic-level sampling with the aim of identifying habitat, lake, and watershed characteristics that are associated with contamination in these parts of the ecosystems as well as higher trophic-level fishes.

More than 90 percent of the MeHg exposure in fish comes from dietary sources (Hall and others, 1997). Thus, differences in the feeding ecology strongly regulate the accumulation of $\mathrm{Hg}$ in tissues (Cabana and others, 1994; Vander Zanden and Rasmussen 1996; Power and others, 2002). The considerable variation in THg concentrations among the three species of fishes sampled from Tanada Lake suggests that variable bioavailability of $\mathrm{MeHg}$ is not the sole determinant of $\mathrm{THg}$ concentrations in these lakes. The two species with the highest THg concentrations (lake trout and burbot) are predominantly piscivorous as adults (Scott and Crossman, 1973; Mittlebach and Persson, 1998), and, therefore, occupy higher trophic positions, which results in higher levels of $\mathrm{Hg}$ biomagnification. In contrast, Arctic grayling tend to forage predominantly on benthic and emergent invertebrates (Armstrong, 1986). THg concentrations in invertivorous grayling were low compared to co-occurring piscivorous species in other areas of Alaska (Allen-Gil and others, 1997; Jewett and others, 2003) and throughout Canada (Lockhart and others, 2005). Although these data indicate that grayling from Tanada Lake typically are younger (median age $=9.5 \mathrm{yr}$ ) than either burbot (12 yr) or lake trout (13 yr), $\mathrm{THg}$ concentrations in burbot and lake trout were consistently higher than in similarly aged grayling. Thus, it is unlikely that age alone could account for the observed variation. However, $\mathrm{THg}$ concentrations were more strongly correlated with age than size. This may indicate the relatively large size of the fish sampled and the asymptotic relationship between age and growth (Rao, 1958; Ricker, 1975), which could result in the decoupling of size-THg relationships once the asymptotic portion of the growth curve is reached. Because the point at which growth asymptotes varies among populations (Chen and others, 1992; Murphy and Willis, 1996), populations may have differing relationships even when age or size structures are similar (for example, lake trout from Tanada Lake compared to Copper Lake in the current study). 
Although Hg exposure risk in WRST was not formally assessed, our data suggest that risk to park fish, wildlife, and humans is variable across lakes and species. Mercury concentrations in fishes from Grizzly Lake and Summit Lake did not exceed any of the guidelines used for comparisons, whereas concentrations in fishes from Copper Lake and Tanada Lake exceeded benchmarks for toxicological risk to fish, birds, and (or) humans (table 3). Despite the fact that only the most conservative benchmarks for bird (90 ng/g ww in whole body) and human (150 ng/g ww in muscle, corresponding to the AK-DHSS unrestricted consumption guideline) were exceeded in lake trout from Copper Lake, a relatively large percentage of individuals exceeded the human benchmark, suggesting that a more detailed evaluation of human consumption risk is warranted. Furthermore, THg concentrations in fishes from Tanada Lake regularly exceeded conservative benchmarks and benchmarks for risk to moderate- and low-sensitivity avian consumers (180 and $270 \mathrm{ng} / \mathrm{g}$ ww in whole body, respectively), as well as the AK-DHSS 4-meal-per-week guideline ( $320 \mathrm{ng} / \mathrm{g} \mathrm{ww}$ in muscle). In particular, most of the burbot and lake trout from Tanada Lake exceeded these benchmarks (table 3). This warrants further considerations because Tanada Lake is a known site of subsistence fisheries (Weeks, 2003; Schwanke and McCormick, 2010; Kukkonen and Zimpelman, 2012). However, our analyses suggest that selectively harvesting smaller individuals is one potential way to reduce human $\mathrm{Hg}$ exposure from Tanada Lake. For example, the model of risk as a function of fish size in Tanada Lake predicted that no burbot less than $365 \mathrm{~mm}$ SL or lake trout less than $348 \mathrm{~mm}$ SL were expected to exceed the AK-DHSS 4-meal-per-week guideline. Conversely, all burbot and lake trout with greater than 546 and $459 \mathrm{~mm} \mathrm{SL}$, respectively, exceeded this guideline. Such insights into the size at which risk thresholds are exceeded provide a valuable basis upon which managers can communicate and mitigate exposure risk to consumers. Nonetheless, the high degree of within-park variability suggests that size thresholds generated for one population may not reflect risk in other populations. Thus, follow-up research and monitoring efforts across sites within the park will be beneficial for adequately characterizing and determining future directions for minimizing risk to park fish, wildlife, and users.

This study provides an important step towards understanding the distribution of $\mathrm{Hg}$ and potential risks posed to park wildlife and visitors. However, our study included only a small fraction of the aquatic resources and habitat types present within WRST. Such limited sampling is unlikely to adequately characterize $\mathrm{Hg}$ risk because of the substantial variation observed within other national parks (Eagles-Smith and others, 2014). Additional quantitative studies of the biogeochemical and food-web processes regulating inter-site and inter-species variation within the park will facilitate more accurate identification of the ecological risks associated with $\mathrm{Hg}$. Finally, it is important that the toxicological effects of $\mathrm{Hg}$ on park fish and wildlife be directly assessed in order to develop risk benchmarks that reflect the species and habitats present in WRST, and, thus, more robustly portray risk to WRST ecosystems as a whole.

\section{Acknowledgments}

This study was funded by Wrangell-St. Elias National Park and Preserve and the U.S. Geological Survey. This study would not have been possible without the facilitation of Molly McCormick at Wrangell-St. Elias National Park and Preserve and the efforts of the park staff that collected samples for analysis. We are grateful for the laboratory assistance provided by John Pierce, Jim Randolph, Austin Shick, and Mason Wagner, as well as database and mapping assistance from Branden Johnson. We thank Andrea Blakesley and Eric Veach for feedback on human risk guidelines, and Dave Sarafin, Angela Matz, Kyle Shedd, and Leah Kenney for providing thoughtful comments on previous versions of this report. 


\section{References Cited}

Allen-Gil, S., Gubala, C.P., Landers, D.H., Lasorsa, B.K., Crecelius, E.A., and Curtis, L.R., 1997, Heavy metal accumulation in sediment and freshwater fish in U.S. arctic lakes: Environmental Toxicology and Chemistry, v. 16, no. 4., p. 733-741.

Armstrong, R.H., 1986, A review of Arctic grayling studies in Alaska: Biological Papers of University of Alaska, 1952-1982, no. 23, p. 3-17.

Beckvar, N., Dillon, T.M., and Read, L.B., 2005, Approaches for linking whole-body fish tissue residues of mercury or DDT to biological effects thresholds: Environmental Toxicology and Chemistry, v. 24, no. 8, p. 2,094-2,105.

Benoit, J.M., Gilmour, C.C., Heyes, A., Mason, R.P., and Miller, C.L., 2003, Geochemical and biological controls over methylmercury production and degradation in aquatic ecosystems, in Cai, Yong, and Braids, O.C., Biogeochemistry of environmentally important trace elements: American Chemical Society Symposium Series 835, p. 262-297, doi:10.1021/bk-2003-0835.ch019.

Black, B., von Biela, V., Zimmerman, C., and Brown, R., 2013, Lake trout otolith chronologies as multidecadal indicators of high-latitude freshwater ecosystems: Polar Biology, v. 36, no. 1, p. 147153.

Burnham, K., and Anderson, D., 2010, Model selection and inference-A practical informationtheoretic approach: New York, Springer, 514 p.

Cabana, G., and Rasmussen, J.B., 1994, Modeling food chain structure and contaminant bioaccumulation using stable nitrogen isotopes: Nature, v. 372, p. 255-257.

Chen, Y., Jackson, D.A., and Harvey, H.H., 1992, A comparison of von Bertalanffy and polynomial functions in modelling fish growth data: Canadian Journal of Fisheries and Aquatic Sciences, v. 49, no. 6 , p. 1,228-1,235.

Committee of Age-Reading Experts, 2006, Manual on generalized age determination procedures for groundfish: Pacific States Marine Fisheries Commission, 52 p., http://care.psmfc.org/docs/CareManual2006.pdf .

Depew, D.C., Basu, N., Burgess, N.M., Campbell, L.M., Evers, D.C., Grasman, K.A., and Scheuhammer, A.M., 2012, Derivation of screening benchmarks for dietary methylmercury exposure for the common loon (Gavia immer) — Rationale for use in ecological risk assessment: Environmental Toxicology and Chemistry, v. 31, no. 10, p. 2,399-2,407.

Driscoll, C.T., Mason, R.P., Chan, H.M., Jacob, D.J., and Pirrone, N., 2013, Mercury as a global pollutant - Sources, pathways, and effects: Environmental Science and Technology, v. 47, no. 10, p. 4,967-4,983.

Durnford, D., Dastoor, A., Figueras-Nieto, D., and Ryjkov, A., 2010, Long range transport of mercury to the Arctic and across Canada: Atmospheric Chemistry and Physics, v. 10, no. 13, p. 6,063-6,086.

Eagles-Smith, C.A., Willacker, J.J., Jr., and Flanagan Pritz, C.M., 2014, Mercury in fishes from 21 national parks in the Western United States - Inter- and intra-park variation in concentrations and ecological risk: U.S. Geological Survey Open-File Report 2014-1051, 54 p.

Evans, M., Muir, D., Brua, R.B., Keating, J., and Wang, X., 2013, Mercury trends in predatory fish in Great Slave Lake-The influence of temperature and other climate drivers: Environmental Science and Technology, v. 47, p. 12,793-12,801.

Evers, D.C., Han, Y.J., Driscoll, C.T., Kamman, N.C., Goodale, M.W., Lambert, K.F., Holsen, T.M., Chen, C.Y., Clair, T.A., and Butler, T., 2007, Biological mercury hotspots in the northeastern United States and southeastern Canada: BioScience, v. 57, no. 1, p. 29-43. 
Greenfield, B.K., Hrabik, T.R., Harvey, C.J., and Carpenter, S.R., 2001, Predicting mercury levels in yellow perch-Use of water chemistry, trophic ecology, and spatial traits: Canadian Journal of Fisheries and Aquatic Sciences , v. 58, p. 1,419-1,429.

Hall, B.D., Bodaly, R.A., Fudge, R.J.P., Rudd, J.W.M., and Rosenberg, D.M., 1997, Food as the dominant pathway of methylmercury uptake by fish: Water, Air, and Soil Pollution, v. 100, nos. 1-2, p. 13-24.

Heinz, G.H., Hoffman, D.J., Klimstra, J.D., Stebbins, K.R., Kondrad, S.L., and Erwin, C.A., 2009, Species differences in the sensitivity of avian embryos to methylmercury: Archives of Environmental Contamination and Toxicology, v. 56, no. 1, p. 129-138.

Hood, E., Eckert, G., Nagorski, S., and Talus, C., 2006, Assessment of coastal water resources and watershed conditions at Wrangell-St. Elias National Park and Preserve, Alaska: National Park Service Technical Report NPS/NRWRD/NRTR-2006-346, 77 p.

Jaffe, D., and Strode, S., 2008, Sources, fate and transport of atmospheric mercury from Asia: Environmental chemistry, v. 5, no. 2, p. 121-126.

Jewett, S.C., Zhang, X., Naidu, S., Kelley, A., Dasher, J., and Duffy, L.K., 2003, Comparison of mercury and methylmercury in northern pike and Arctic grayling from western Alaska rivers: Chemosphere, v. 50, no. 3, p. 383-392.

Kenow, K.P., Hoffman, D.J., Hines, R.K., Meyer, M.W., Bickham, J.W., Matson, C.W., Stebbins, K.R., Montagna, P., and Elfessi, A., 2008, Effects of methylmercury exposure on glutathione metabolism, oxidative stress, and chromosomal damage in captive-reared common loon (Gavia immer) chicks: Environmental Pollution, v. 156, no. 3, p. 732-738.

Kenow, K.P., Meyer, M.W., Rossmann, R., Gendron-Fitzpatrick, A., and Gray, B.R., 2011, Effects of injected methylmercury on the hatching of common loon (Gavia immer) eggs: Ecotoxicology, v. 20, no. 7, p. 1,684-1,693.

Kukkonen, M., and Zimpelman, G., 2012, Subsistence harvests and uses of wild resources in Chistochina, Alaska, 2009: Anchorage, Alaska Department of Fish and Game, Division of Subsistence Technical Paper No. 370.

Landers, D.H., Simonich, S.L., Jaffe, D.A., Geiser, L.H., Campbell, D.H., Schwindt, A.R., Schreck, C.B., Kent, M.L., Hafner, W.D., Taylor, H.E., Hagman, K.J., Usenko, S., Ackerman, L.K., Schrlau, J.E., Rose, N.L., Blett, T.F., and Erway, M.M., 2008, The fate, transport, and ecological impacts of airborne contaminants in western national parks (USA): U.S. Environmental Protection Agency Report EPA/600/R-07/138, Office of Research and Development, NHEERL, Western Ecology Division, Corvallis, Oregon.

Lavoie, R.A., Jardine, T.D., Chumchal, M.M., Kidd, K.A., and Campbell, L.M., 2013, Biomagnification of mercury in aquatic food webs - A worldwide meta-analysis: Environmental Science and Technology, v. 47, no. 23, p. 13,385-13,394.

Lockhart, W.L., Stern, G.A., Low, G., Hendzel, M., Boila, G., Roach, P., Evans, M.S., Billneck, B.N., DeLaronde, J., Frieson, S., Kidd, K., Atkins, S., Muir, D.C.G., Stoddart, M., Stephens, G., Stephenson, S., Harbicht, S., Snowshoe, N., Grey, B., Thompson, S., and DeGraff, N., 2005, A history of total mercury in edible muscle of fish from lakes in northern Canada: Science of the Total Environment, v. 351, p. 427-463.

Mitro, M.G., Evers, D.C., Meyer, M.W., and Piper, W.H., 2008, Common loon survival rates and mercury in New England and Wisconsin: Journal of Wildlife Management, v. 72, no. 3, p. 665-673. Mittelbach, G.G., and Persson, L., 1998, The ontogeny of piscivory and its ecological consequences: Canadian Journal of Fisheries and Aquatic Sciences, v. 55, no. 6, p. 1,454-1,465. 
Murphy, B.R., and Willis, D.W., eds., 1996, Fisheries techniques, 2nd edition: American Fisheries Society, $732 \mathrm{p}$.

Panfili, J., De Pontual, H., Troadec, H., and Wright, P., 2002, Manual of fish sclerochronology: Brest, France, Ifremer-IRD coedition, $464 \mathrm{p}$.

Peterson, S., Van Sickle, J., Hughes, R., Schacher, J., and Echols, S., 2005, A biopsy procedure for determining filet and predicting whole-fish mercury concentration: Archives of Environmental Contamination and Toxicology, v. 48, no. 1, p. 99-107.

Phillips, V.J., St Louis, V.L., Cooke, C.A., Vinebrooke, R.D., and Hobbs, W.O., 2011, Increased mercury loadings to western Canadian alpine lakes over the past 150 years: Environmental Science and Technology, v. 45, no. 6, p. 2,042-2,047.

Power, M., Klein, G.M., Guiguer, K.R.R.A., and Kwan, M.K.H., 2002, Mercury accumulation in the fish community of a sub-Arctic lake relation to trophic position and carbon sources: Journal of Applied Ecology, v. 39, no. 5, p. 819-830.

Rao, C.R., 1958, Some statistical methods for comparison of growth curves: Biometrics, v. 14, p. 1-17. Ricker, W.E., 1975, Computation and interpretation of biological statistics of fish populations: Fisheries Research Board of Canada, Bulletin 191, 382 p.

Sandheinrich, M.B., Bhavsar, S.P., Bodaly, R.A., Drevnick, P.E., and Paul, E.A., 2011, Ecological risk of methylmercury to piscivorous fish of the Great Lakes region: Ecotoxicology, v. 20, no. 7, p. 1,5771,587 .

Scheuhammer, A.M., Basu, N., Burgess, N.M., Elliott, J.E., Campbell, G.D., Wayland, M., Champoux, L., and Rodrigue, J., 2008, Relationships among mercury, selenium, and neurochemical parameters in common loons (Gavia immer) and bald eagles (Haliaeetus leucocephalus): Ecotoxicology, v. 17, no. 2, p. 93-101.

Scheuhammer, A.M., Meyer, M.W., Sandheinrich, M.B., and Murray, M.W., 2007, Effects of environmental methylmercury on the health of wild birds, mammals, and fish: AMBIO - A Journal of the Human Environment, v. 36, no. 1, p. 12-19.

Schwanke, C.J., and McCormick, M.B., 2010, Stock assessment and biological characteristics of burbot in Tanada Lake, 2007 and Copper Lake, 2008: Anchorage, Alaska Department of Fish and Game Fishery Data Series No. 10-62, Final Report for Study 07-501.

Schwindt, A.R., Fournie, J.W., Landers, D.H., Schreck, C.B., and Kent, M.L., 2008, Mercury concentrations in salmonids from western US national parks and relationships with age and macrophage aggregates: Environmental Science and Technology, v. 42, no. 4, p. 1,365-1,370.

Scott, W.B., and Crossman, E.J., 1973, Freshwater fishes of Canada: Fisheries Research Board of Canada Bulletin, v. 184. no. 86, p. 1,026.

Snodgrass, J.W., Jagoe, C.H., Bryan, A.L., Brant, H.A., and Burger, J., 2000, Effects of trophic status and wetland morphology, hydroperiod, and water chemistry on mercury concentrations in fish: Canadian Journal of Fisheries and Aquatic Sciences, v. 57, p. 171-180. 
Sousanes, P., 2012, Annual climate summary 2008 - Central Alaska Network: National Park Service Natural Resource Data Series NPS/CAKN/NRDS-2012/245.

Ullrich, S.M., Tanton, T.W., and Abdrashitova, S.A., 2001, Mercury in the aquatic environment-A review of factors affecting methylation: Critical Review in Environmental Science and Technology, v. 31, no. 3, p. 241293.

U.S. Environmental Protection Agency, 2000, Method 7473, Mercury in solids and solutions by thermal decomposition, amalgamation, and atomic absorption spectrophotometry, test methods for evaluating solid waste, physical/chemical methods SW 846: U.S. Environmental Protection Agency, Update IVA.

Vander Zanden, M.J., and Rasmussen, J.B., 1996, A trophic position model of pelagic food websImpact on contaminant bioaccumulation in lake trout: Ecological Monographs, p. 451-477.

Verbrugge, L.A., 2007, Fish consumption advice for Alaskans-A risk management strategy to optimize the public's health: State of Alaska Epidemiology Bulletin, v. 11, no. 4, p. 1-39.

Watras, C.J., Back, R.C., Halvorsen, S., Hudson, R.J.M., Morrison, K.A., and Wente, S.P., 1998, Bioaccumulation of mercury in pelagic freshwater food webs: Science of the Total Environment, $\mathrm{v}$. 219, nos. 2-3, p. 183-208.

Weeks, D.P., 2003, Wrangell-St. Elias National Park and Preserve, Alaska, Water resources scoping report: National Park Service, Technical Report NPS/NRWRD/NRTR-2003/213, 114 p.

Wiener, J.G., Knights, B.C., Sandheinrich, M.B., Jeremiason, J.D., Brigham, M.E., Engstrom, D.R., Woodruff, L.G., Cannon, W.F., and Balogh, S.J., 2006, Mercury in soils, lakes, and fish in Voyageurs National Park (Minnesota) - Importance of atmospheric deposition and ecosystem factors:

Environmental Science and Technology, v. 40, p. 6,261-6,268.

Wiener, J., and Spry, J., 1996, Toxicological significance of mercury in freshwater fish, in Beyer, W.N, Heinz, G.H., and Redmon-Norwood, A.W., eds, Environmental contaminants in wildlifeInterpreting tissue concentrations: Boca Raton, Florida, Lewis Publishers, p. 297-339. 
Appendix 1. Equations for Converting Standard Length (SL, in millimeters) to Total Length (TL, in millimeters) for Four Species of Fish Sampled from Wrangell-St. Elias National Park and Preserve, Alaska.
Arctic grayling: $\quad \mathrm{TL}=1.0312 * \mathrm{SL}+23.116 ; \mathrm{n}=10 ; \mathrm{R}^{2}=0.9944 ; \mathrm{P}<0.0001$
burbot:
$\mathrm{TL}=1.11 * \mathrm{SL}+7.6252 ; \mathrm{n}=24 ; \mathrm{R}^{2}=0.9866 ; \mathrm{P}<0.0001$
lake trout:
$\mathrm{TL}=1.1643 * \mathrm{SL}+18.84 ; \mathrm{n}=30 ; \mathrm{R}^{2}=0.9754 ; \mathrm{P}<0.0001$
rainbow trout:
$\mathrm{TL}=1.1386 * \mathrm{SL}+4.6143 ; \mathrm{n}=15 ; \mathrm{R}^{2}=0.9974 ; \mathrm{P}<0.0001$ 


\section{Appendix 2. Size at Which the Proportion of Modeled Individuals of Each Species from Tanada Lake Exceeded Defined Toxicity Benchmarks in Wrangell- St. Elias National Park and Preserve, Alaska.}

\begin{tabular}{|c|c|c|c|c|c|c|}
\hline \multirow[b]{3}{*}{ Species } & \multicolumn{6}{|c|}{ Fish Toxicity } \\
\hline & \multicolumn{3}{|c|}{$\begin{array}{c}\text { NOERa } \\
(200 \mathrm{ng} / \mathrm{g})\end{array}$} & \multicolumn{3}{|c|}{$\begin{array}{c}\text { LOER }^{b} \\
(300 \mathrm{ng} / \mathrm{g})\end{array}$} \\
\hline & $0 \%$ & $50 \%$ & $100 \%$ & $0 \%$ & $50 \%$ & $100 \%$ \\
\hline Arctic grayling & -- & -- & -- & -- & - & - \\
\hline burbot & 370 & 492 & 559 & 463 & - & - \\
\hline lake trout & 356 & 398 & 470 & 432 & $\ldots$ & - \\
\hline
\end{tabular}

${ }^{\mathrm{a}}$ No-Observed-Effects-Residue (Beckvar and others, 2005).

${ }^{\mathrm{b}}$ Lowest-Observed-Effects-Residue (Sandheinrich and others, 2011).

\begin{tabular}{|c|c|c|c|c|c|c|c|c|c|}
\hline \multirow[b]{2}{*}{ Species } & \multicolumn{3}{|c|}{$\begin{array}{l}\text { High Sensitivity } \\
(90 \mathrm{ng} / \mathrm{g})\end{array}$} & \multicolumn{3}{|c|}{$\begin{array}{c}\text { Bird Toxicity } \\
\text { Moderate Sensitivity } \\
(180 \mathrm{ng} / \mathrm{g})\end{array}$} & \multicolumn{3}{|c|}{$\begin{array}{l}\text { Low Sensitivity } \\
(270 \mathrm{ng} / \mathrm{g})\end{array}$} \\
\hline & $0 \%$ & $50 \%$ & $100 \%$ & $0 \%$ & $50 \%$ & $100 \%$ & $0 \%$ & $50 \%$ & $100 \%$ \\
\hline Arctic grayling & 308 & 336 & -- & -- & -- & -- & -- & -- & -- \\
\hline burbot & $<345$ & $<345$ & 377 & 346 & 468 & 535 & 439 & 561 & -- \\
\hline lake trout & $<330$ & $<330$ & $<330$ & 337 & 378 & 450 & 413 & 454 & - \\
\hline
\end{tabular}

\begin{tabular}{|c|c|c|c|c|c|c|c|c|c|}
\hline \multirow[b]{2}{*}{ Species } & \multicolumn{3}{|c|}{$\begin{array}{l}\text { Unrestricted Consumption } \\
\qquad(150 \mathrm{ng} / \mathrm{g})\end{array}$} & \multicolumn{3}{|c|}{$\begin{array}{l}\text { Human Toxicity } \\
4 \text { Meals per Week } \\
(320 \mathrm{ng} / \mathrm{g})\end{array}$} & \multicolumn{3}{|c|}{$\begin{array}{l}2 \text { Meal per Week } \\
(640 \mathrm{ng} / \mathrm{g})\end{array}$} \\
\hline & $0 \%$ & $50 \%$ & $100 \%$ & $0 \%$ & $50 \%$ & $100 \%$ & $0 \%$ & $50 \%$ & $100 \%$ \\
\hline Arctic grayling & 315 & -- & -- & -- & -- & -- & -- & -- & - \\
\hline burbot & $<345$ & $<345$ & 396 & 365 & 484 & 546 & 503 & -- & -- \\
\hline lake trout & $<330$ & $<330$ & 335 & 348 & 391 & 459 & 461 & -- & -- \\
\hline
\end{tabular}


Publishing support provided by the U.S. Geological Survey Publishing Network, Tacoma Publishing Service Center

For more information concerning the research in this report, contact the Director, Forest and Rangeland Ecosystem Science Center U.S. Geological Survey

777 NW 9th St., Suite 400

Corvallis, Oregon 97330

http://fresc.usgs.gov/ 
